\title{
Ontwikkelingsmogelijkheden voor de agrarische sector in Caribisch Nederland
}

L.A.P. Lotz, A.O. Debrot, F. Neijenhuis, C. Stanghellini en R.E.E. Jongschaap

Wageningen University \& Research

Dit onderzoek is in opdracht van de Tweede Kamer der Staten-Generaal uitgevoerd door de Stichting Wageningen Research (WR).

WR is een onderdeel van Wageningen University \& Research, samenwerkingsverband tussen Wageningen University en de Stichting Wageningen Research.

Wageningen, december 2020

Rapport WPR-1026

WAGENINGEN

UNIVERSITY \& RESEARCH
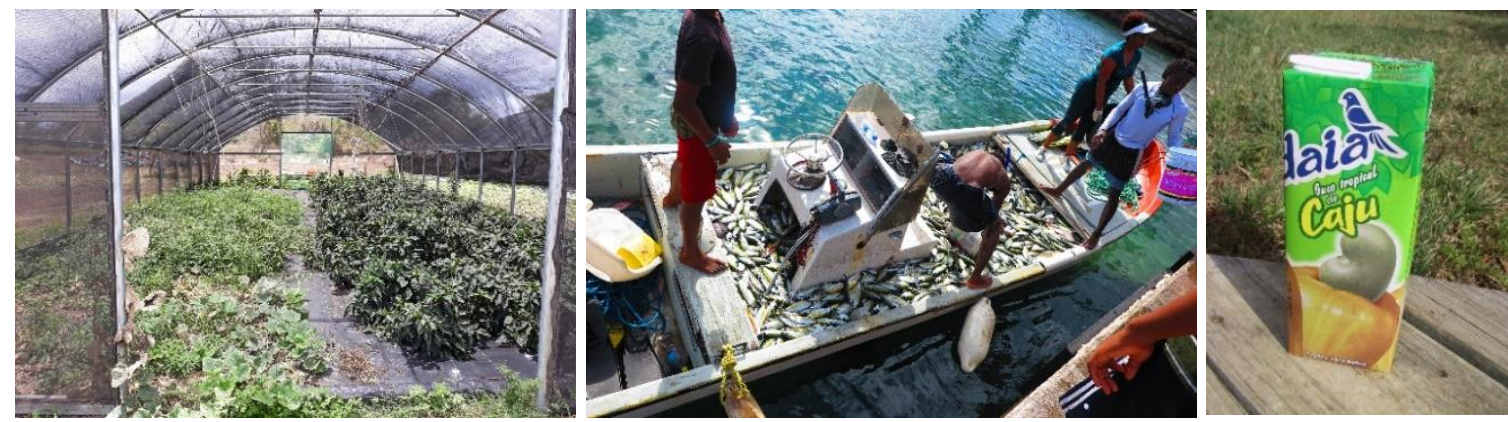
Lotz L.A.P., A.O. Debrot, F. Neijenhuis, C. Stanghellini en R.E.E. Jongschaap, 2020.

Ontwikkelingsmogelijkheden voor de landbouw in Caribisch Nederland, Wageningen University \& Research, Rapport WPR-1026. 46 blz.; 9 fig.; 1 tab.; 66 ref.

Dit rapport is gratis te downloaden op https://doi.org/10.18174/536176.

Samenvatting De huidige voedselproductie op de eilanden Bonaire, Sint Eustatius en Saba is beperkt. Zowel de overheid als de lokale bevolking hebben de afgelopen jaren initiatieven genomen om de voedselproductie te verhogen. Deze studie trekt daar lering uit en komt met concrete aanbevelingen voor zowel het beleid als de sector (land- en tuinbouw, veeteelt en visserij). Centraal staan, voor elk van de drie eilanden, vier op te stellen plannen: een integraal zoetwaterplan, een agrarisch ontwikkelplan, een visserijontwikkelplan en een agrarisch onderwijsplan. Dit onderwijsplan moet leiden tot een grotere interesse voor lokale voedselproductie bij jongeren en dient zich te richten op kennis en vaardigheden ten behoeve van zowel duurzame innovatieve intensivering van productiesystemen als professionele voedselproductie in combinatie met nevenactiviteiten met betrekking tot toerisme of zorg.

Trefwoorden: Caribisch Nederland, duurzame voedselproductie, zoetwaterplan, agrarisch ontwikkelplan, visserijontwikkelplan, agrarisch onderwijsplan.

(C) 2020 Wageningen, Stichting Wageningen Research, Wageningen Plant Research, Business unit Agrosystems Research, Postbus 16, 6700 AA Wageningen; T 03174807 00; www.wur.nl/plantresearch

KvK: 09098104 te Arnhem

VAT NL no. 8113.83.696.B07

Stichting Wageningen Research. Alle rechten voorbehouden. Niets uit deze uitgave mag worden verveelvoudigd, opgeslagen in een geautomatiseerd gegevensbestand, of openbaar gemaakt, in enige vorm of op enige wijze, hetzij elektronisch, mechanisch, door fotokopieën, opnamen of enige andere manier zonder voorafgaande schriftelijke toestemming van Stichting Wageningen Research.

Stichting Wageningen Research is niet aansprakelijk voor eventuele schadelijke gevolgen die kunnen ontstaan bij gebruik van gegevens uit deze uitgave.

\section{Rapport WPR-1026}

Foto's omslag: Overdekte groenten en kruidenteelt op basis van dripsysteem (Dolfi Debrot), Sint Eustatius; Kleine pelagische scholende vissoort (Kimani Kitson-Walters); Cashewsap zoals op kleine schaal verpakt voor de verkoop (Dolfi Debrot). 


\section{Inhoud}

$\begin{array}{ll}\text { Woord vooraf } & 5\end{array}$

$\begin{array}{ll}\text { Samenvatting } & 6\end{array}$

$\begin{array}{ll}\text { Summary } & 8\end{array}$

$\begin{array}{lr}1 & 10\end{array}$

1.1 Vraagstelling $\quad 12$

1.2 Werkwijze 12

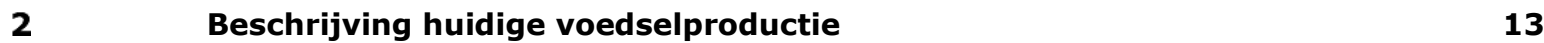

$3 \quad$ Factoren die bepalend zijn voor de kansen van landbouw 17

$\begin{array}{lll}3.1 & \text { Waterbeschikbaarheid en watergebruik } & 17\end{array}$

3.2 Beschikbaarheid van land en geschiktheid van de bodem 19

$\begin{array}{lll}3.3 & \text { Ondersteuning door lokale overheden } & 20\end{array}$

3.4 Conflicterende belangen (begrazing, toerisme) 22

3.5 Regelgeving $\quad 22$

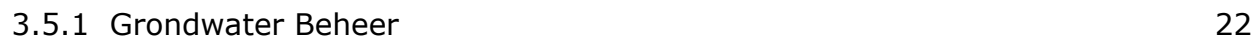

3.5.2 Preventie en bestrijding van invasieve exotische soorten 23

3.5.3 Gewasbescherming 23

$\begin{array}{ll}3.5 .4 \text { Dierenwelzijn en voedselveiligheid } & 23\end{array}$

$\begin{array}{lll}3.6 & \text { Veiligheid/diefstal 'buitengebied' } & 24\end{array}$

3.7 Afzetmogelijkheden/belemmeringen in de keten $\quad 24$

$\begin{array}{lll}3.8 & \text { Lokale culturr } & 25\end{array}$

4 Initiatieven om de voedselproductie te verhogen $\quad 27$

$\begin{array}{lll}4.1 & \text { Overzicht van initiatieven } & 27\end{array}$

4.2 Geiten 30

4.3 Innovatieve systemen voor groenteproductie 33

4.4 Visserij - naar een meer gebalanceerd systeem $\quad 35$

5 Welke kansen geven de lessen uit het verleden in combinatie met nieuwe $\begin{array}{ll}\text { inzichten } & \mathbf{3 8}\end{array}$

5.1 Meer algemene lessen 38

5.2 Zoetwater $\quad 39$

$\begin{array}{lll}5.3 & \text { Landbouw } & 39\end{array}$

$\begin{array}{lll}5.4 & \text { Visserij } & 41\end{array}$

$\begin{array}{lll}5.5 & \text { Onderwijs } & 41\end{array}$

6 Dankwoord $\quad 42$

$\begin{array}{ll}\text { Literatuur } & 43\end{array}$ 


\section{Woord vooraf}

De vaste commissie voor Koninkrijkrelaties heeft in de kennisagenda 2019 het thema ontwikkeling landbouw Caribisch Nederland benoemd als één van de onderwerpen waar zij extra kennisversterking op wenst. Achterliggende visie is dat de eilanden Bonaire, Sint Eustatius en Saba gebaat zijn bij een grotere mate van zelfvoorziening t.a.v. het produceren van voedsel dan op dit moment gerealiseerd wordt. Voor de landen Curaçao, Aruba en Sint Maarten geldt overigens hetzelfde.

De vaste commissie voor Koninkrijkrelaties is opdrachtgever van deze studie. Zij vraagt een studie die primair gericht is op Bonaire, Sint Eustatius en Saba. De commissie wil een beknopt, maar goed beeld krijgen van de mogelijkheden voor de agrarische sector in Caribisch Nederland (inclusief visserij).

Daarmee zijn de leden van deze vaste commissie voor Koninkrijkrelaties de primaire doelgroep van deze rapportage. Aangezien dit onderzoek gericht is op het bieden van oplossingsrichtingen voor partijen die betrokken zijn bij landbouwontwikkeling op de drie eilanden zijn de drie Openbare lichamen, het ministerie van LNV en de Tweede Kamer doelgroep in brede zin.

Het projectteam heeft dankbaar gebruik gemaakt van commentaar en aanvullingen op de conceptrapportage door plaatselijke deskundigen (zie dankwoord Hoofdstuk 6). 


\section{Samenvatting}

De huidige voedselproductie op de eilanden Bonaire, Sint Eustatius en Saba is beperkt. Het meeste voedsel wordt ingevoerd vanuit omringende landen. Deze studie heeft als doel de huidige stand van zaken voor lokale agrarische productie te beschrijven voor deze drie eilanden, ontwikkelingskansen te benoemen en aan te geven hoe deze op hoofdlijnen te realiseren zijn.

De verduurzaming van de lokale voedselproductie en visserij is een geïntegreerd onderdeel van het tienjarige Natuur- en Milieubeleidsplan voor Caribisch Nederland 2020-2030. Een duurzame lokale voedselproductie als bijdrage aan de lokale economie, behoort daarmee tot de expliciete doelstellingen van dit beleidsplan.

Zowel de overheid als de lokale bevolking hebben de afgelopen jaren diverse initiatieven genomen om de voedselproductie te verhogen. Deze initiatieven zijn op basis van literatuuronderzoek en aanvullende informatie van lokale experts geëvalueerd. Opmerkelijk is dat meer gedetailleerde projectbeschrijvingen en verslaglegging van deze initiatieven in het openbare domein veelal ontbreken. Dit compliceerde de duiding van de effecten van deze initiatieven en het afleiden van wat daaruit geleerd kan worden. Toch bleken, met een helicopterview, wel degelijk onderbouwde aanbevelingen opgesteld te kunnen worden om de agrarische ontwikkelingsmogelijkheden in dit deel van Nederland te verbeteren. Hieronder volgen de belangrijkste daarvan.

Aansluitend op het Natuur- en Milieubeleidsplan dienen voor elk van de eilanden vier meer toegespitste plannen opgesteld te worden: een integraal zoetwaterplan, een agrarisch ontwikkelplan, een visserijontwikkelplan en een agrarisch onderwijsplan. De ontwikkeling en implementatie van deze plannen zijn op veel vlakken van elkaar afhankelijk voor succes en dienen dan ook per eiland gekoppeld ontwikkeld en uitgerold te worden.

Een integraal zoetwaterplan waar duurzaam beheer van het grondwater en circulaire (op basis van hergebruik) en waterbesparende productiesystemen deel van uit maken, is cruciaal.

Daaraan gekoppeld is een geactualiseerd agrarisch ontwikkelingsplan noodzakelijk. In dit plan moeten concrete acties worden uitgewerkt, zoals het actualiseren van bodemkaarten ten behoeve van duurzaam bodembeheer, het opstellen van structurele oplossingen van problemen veroorzaakt door loslopende geiten en het actualiseren van regelgeving ten aanzien van gewasbescherming. Daarnaast dienen dierenwelzijn en voedselveiligheid (de huidige regelgeving wijkt deels af van die in Europees Nederland) en verbetering van de algemene veiligheid in het buitengebied van Bonaire, als belangrijke voorwaarde voor nieuwe investeringen in innovatieve teelt- en bedrijfssystemen. Tenslotte is een uitwerking nodig van opties hoe de winstgevendheid, en daarmee de concurrentiekracht ten opzichte van buitenlandse voedselimport verhoogd kan worden. Het zou goed zijn als de lokale overheden en Ministerie van LNV samen met telers en andere betrokkenen per eiland daarbij een goed onderbouwde visie ontwikkelen over hoe in kaart gebrachte opties beter benut kunnen worden om de winstgevendheid van de eigen voedselproductie te verhogen.

De verdere ontwikkeling van visserij op meer open water en op soorten die aan of bij het wateroppervlak leven, biedt goede kansen tot duurzame uitbreiding van de visserijsector. Deze ontwikkeling moet gepaard gaan met maatregelen om de overbevissing van de kustgebonden bodemvissen terug te dringen. Hiertoe dient een breed gedragen visserijontwikkelplan te worden geschreven met wetenschappelijk onderbouwde richtlijnen en met monitoringsdata als basis, om aan te geven wat concreet te doen staat om overbevissing te voorkomen en duurzaamheid in te bouwen.

Of het nu vlees- of groenteproductie of de visserij betreft, in alle gevallen moet een meerjarige aanpak - dus ook meerjarige, structurele financiering - uitgangspunt zijn, met goede kwantitatieve 
monitoring en rapportage, ook tussentijds. Kennisontwikkeling moet parallel blijven meelopen om knelpunten tijdig op te lossen.

Betrokkenheid van de bevolking bij de planvorming dient gewaarborgd te zijn, waarbij rekening gehouden wordt met deels eilandgebonden cultuuraspecten en andere factoren die maatschappelijke acceptatie bepalen. Het zoeken van meekoppelkansen (win-win mogelijkheden) die goed passen in de lokale context per eiland, kunnen helpen het noodzakelijke draagvlak van een initiatief te vergroten.

Tenslotte, het imago en de attractiviteit van de land- en tuinbouwsector in Caribisch Nederland lijkt op dit moment niet groot. Een agrarisch onderwijsplan moet leiden tot een grotere interesse voor lokale voedselproductie bij jongeren. Een te ontwikkelen curriculum, vanaf de basisschool met focus op het middelbaar beroepsonderwijs, dient zich te richten op kennis en vaardigheden ten behoeve van zowel duurzame innovatieve intensivering van productiesystemen als professionele voedselproductie in combinatie met nevenactiviteiten met betrekking tot toerisme of zorg. Een recent initiatief daartoe op Bonaire, in samenwerking met de groene kennisinstelling AERES Hogeschool, verdient ondersteuning en kan ook verder uitgerold worden op Sint Eustatius en Saba. 


\section{Summary}

Current food production on the islands of Bonaire, Sint Eustatius and Saba is limited. Most food is imported from surrounding countries. The objectives of this study were to assess the current state of affairs with respect to agricultural production in the Caribbean Netherlands, to identify opportunities for development of the agricultural sector, and to indicate most promising pathways to realize these.

The development of sustainable local food production and fisheries is an integral component of the ten-year Nature and Environmental Plan for the Caribbean Netherlands 2020-2030. Herein a contribution of sustainable local food production to the local economy is indicated as an explicit goal.

In recent years, the island governments and private parties have undertaken numerous initiatives in an effort to increase local food production and food security. In this report we evaluated these initiatives based on a survey of reports, publications and online sources, and supplemented this with additional information obtained from local experts. Notable is the general lack of detailed project description and reporting on these initiatives in the public domain. This makes it complicated to properly identify their impact in terms of failures or success and to derive lessons learnt from all the efforts made. However, based on a broader helicopter view, firm recommendations could be derived to support the development of agricultural opportunities in this part of The Netherlands. We here summarize our main recommendations.

In addition to the present Nature and Environmental policy plan 2020-2030, for each island four more narrowly defined plans will be needed in order to structurally develop the identified opportunities. These are an integral freshwater plan, an agricultural development plan, a fisheries development plan and an agricultural education plan. The development and implementation of these plans are interdependent in several ways. Therefore, they will need to be developed and implemented in parallel and in connection to each other.

An integral freshwater plan whereby sustainable management and exploitation of groundwater and the use of circular and water saving agricultural production systems are accounted for, is essential.

Coupled to this, a modern agricultural development plan will be necessary. The plan needs to identify and concretize interventions, tools and actions, among which a) derive new and up-to-date soil maps for sustainable soil management and conservation, b) a plan to address the persistent and destructive roaming goats issue, c) the development and implementation of up-to-date legislation regarding the use of pesticides and herbicides, d) addressing animal welfare and food safety issues, and e) improving the general security situation in rural agricultural areas of Bonaire. These are all essential as a basis for new interest and investment in innovative culture agricultural production systems and business ventures in the agricultural sector. Finally, further studies are required to identify options how to improve profitability to address the experienced competition from cheaper imports. We recommend local governments and the Ministry of Agriculture, Nature and Food Quality to join forces with local entrepreneurs and stakeholders to develop a well-founded vision on how to best make use of and implement various options to increase success and profitability for local food production initiatives.

The development of open waters fisheries targeting especially small pelagic species offers yet untapped opportunities for a sustainable expansion of the fishery sector. This should take place in concordance with additional measures to reduce the current level of overfishing of coastal-bound demersal coral reef-based fish stocks. For this, a broadly supported fisheries development plan is needed based on scientific guidelines and monitoring to serve as a basis to integrate sustainable fish population management in the sector. 
Whether it is animal husbandry, horticulture or fisheries, in all cases a multi-year long-term approach will be necessary with periodic quantitative monitoring and reporting. Knowledge development must also advance in parallel, to address bottlenecks in a timely and dedicated manner. Developed knowledge should be secured to assess similar local problems in primary production systems in the future. The involvement of the local population and stakeholders needs to be safeguarded from the beginning whereby it will be necessary to take island-bound, local cultural differences into account to increase the chances of local acceptance. It will be necessary to seek and find local opportunities of coupling the initiatives toward synergy and additional spin-off that fit the local socio-economic context and that can help to further improve grass-roots support.

Finally, the image and attractiveness of the agriculture and horticulture sector in the Netherlands Caribbean are presently very low. Therefore, an agricultural education plan will need to be developed and implemented in order to increase local interest and support for local food production, especially amongst the youth. A curriculum for the local secondary and vocational level education will be needed to develop basic knowledge, appreciation and skills as an essential basis for innovative intensification of agricultural production systems, in combination with related opportunities in tourism and social care systems. A recent initiative towards this on Bonaire deserves support and roll-out all of the Netherlands Caribbean. 


\section{Inleiding}

De eilanden Bonaire, Sint Eustatius en Saba vormen samen Caribisch Nederland. Zij worden ook wel aangeduid als de BES-eilanden. Sint Eustatius en Saba maken deel uit van de Bovenwindse Eilanden, terwijl Bonaire deel uitmaakt van de Benedenwindse Eilanden. Deze drie eilanden hebben vanaf 1010-2010 de status van Openbaar Lichaam (daarmee in feite functionerend als een soort gemeente) binnen het land Nederland. De drie eilanden hebben alle een tropisch klimaat en de sociale organisatie van een klein eiland, maar zijn verder onderling duidelijk verschillend. Verschillen zijn er zowel in bevolking, cultuur als in landschap.

Waar de eilanden juist in overeenkomen is dat het meeste voedsel ingevoerd wordt vanuit omringende landen (Bogaardt et al., 2015). De meeste aanvoer van producten voor Bonaire gaat via Curaçao en is vooral afkomstig uit de Verenigde Staten en West-Europa. Voor individuele producten kan dat anders zijn (o.a. Brazilië, Jamaica, Colombia) (Meindert et al., 2017). Sint Eustatius en Saba zijn vooral afhankelijk van doorvoer vanuit Sint Maarten. De import van deze Bovenwindse eilanden komt vanuit allerlei landen, onder andere uit de Verenigde Staten, Canada en de Dominicaanse Republiek (Bogaardt et al., 2015). Mede door de import- en transportkosten zijn de voedselprijzen op de drie eilanden relatief hoog (Meindert et al., 2017).

Op Bonaire, Sint Eustatius en Saba is de voedselproductie gering en veelal voor eigen gebruik. De omvang van de professionele teelt van groente, fruit en vlees is zeer beperkt. Ook de visserij functioneert op deze eilanden suboptimaal (Debrot \& De Graaf, 2018b). Vanuit de Openbare lichamen, de nationale overheid (Ministerie van LNV) en de bevolking zijn er al enkele jaren initiatieven om daar iets aan te doen.

Tot 40-50 jaar geleden was er op de eilanden veel meer land- en tuinbouw (Freitas et al., 2005; 2014; 2016). Sindsdien zijn veel terreinen niet meer in agrarisch gebruik. Redenen voor de teruggang van eigen productie zijn de stijgende welvaart en de mogelijkheden om te importeren tegen sterk concurrerende prijzen uit landen waar de productiekosten lager zijn. Dit ging gepaard met verminderende belangstelling van de eilandbewoners in eigen land- en tuinbouw, waardoor de afhankelijkheid van import verder toenam.

In het buitengebied, en met name op de verlaten gronden, treedt relatief veel bodemerosie op, doordat daar een gewoonte is ontstaan om geiten, schapen, ezels en op Sint Eustatius ook koeien, vrij te laten grazen. Bodemerosie treedt dan op door (over-) begrazing van de vegetatie waardoor bomen, struik- en plantenwortels afsterven en de grond niet meer beschermd wordt. Deze bodemerosie vormt, als sedimenten afspoelen in de zee, een directe bedreiging voor de koraalecosystemen (Figuur 1). Roberts et al. (2017) hebben de relatie vastgelegd tussen landdegradatie (door overbegrazing en erosie) en de verslechtering van de gezondheid van het koraalrif bij Bonaire. Oorzaken van deze verslechtering zijn beperking van de lichtdoordringing naar het rif door vertroebeling van het water door het afstromend sediment, bedekking van het rif door sedimentatie en eutrofiering (overbemesting van het water door oplossende nutriënten van het afstromend sediment). 


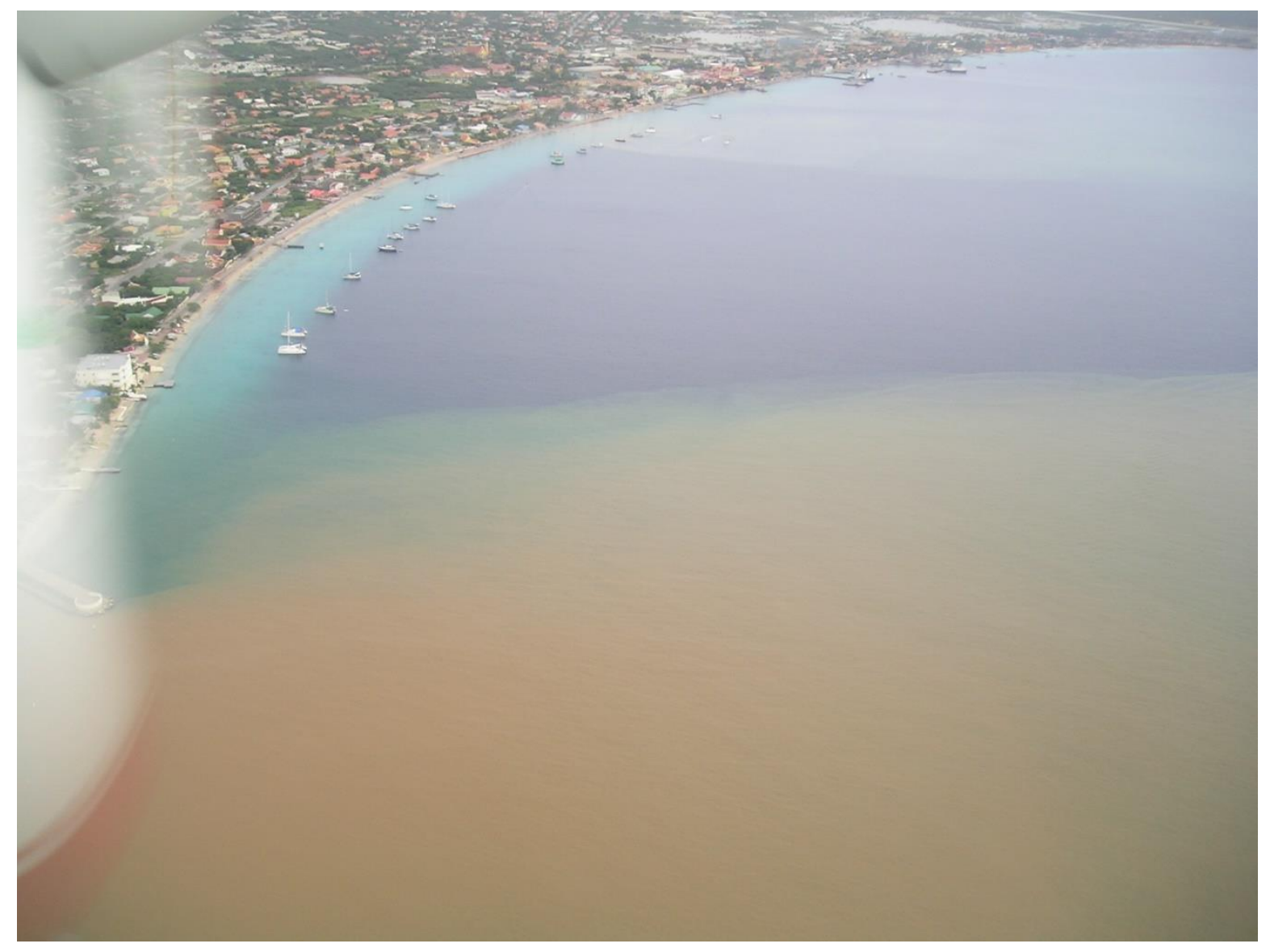

Figuur 1 Foto vanuit een vliegtuigraam. Geërodeerde modder met nutriënten zorgt voor verminderde lichtdoordringing en bedelven het koraalrif met sediment na een plensbui op Bonaire (Foto: Frank van Slobbe).

Verder blijken juist de gebieden die uit agrarisch gebruik zijn genomen, belangrijke vestigingsplaatsen te zijn voor invasieve exotische plantensoorten, zoals op Sint Eustatius de woekerplant Corallita (Antigonon leptopus) oorspronkelijk afkomstig uit Midden-Amerika. Deze snel uitbreidende exotische plantensoorten houden de bodem vaak minder goed vast dan lokale soorten, wat leidt tot allerlei ecologische en economische problemen (Burg et al., 2012).

De verduurzaming van de visserij en de lokale voedselproductie is nu geïntegreerd in het tienjarige Natuur- en Milieubeleidsplan voor Caribisch Nederland 2020-2030 (Ministeries van LNV, I\&W \& BZK, 2020). Een duurzame visserij en duurzame lokale voedselproductie behoren daarmee tot de expliciete doelstellingen van het beleidsplan dat nu belangrijke referentiekaders biedt voor de ontwikkeling van de agrarische sector van deze eilanden.

Tenslotte, de afname in lokale agrarische activiteit en daarmee de productie en beschikbaarheid van betaalbaar vers en gezond voedsel, heeft gevolgen gehad voor de voedselconsumptiepatronen, met een mogelijk effect op de volksgezondheid. Er wordt op de eilanden meer suiker- en vetrijk voedsel geconsumeerd. Dit leidt tot een toename in welvaartsziekten zoals overgewicht, hart- en vaatziekten en diabetes (Bogaardt et al., 2015; Sociaal Cultureel Planbureau, 2015; UNICEF NL, 2019).

Afgelopen jaren zijn er al verschillende studies en initiatieven geweest met als doel de agrarische productie en visserij op de drie eilanden nieuw leven in te roepen, bij voorkeur met een sterke inbreng van de lokale bevolking. De vaste commissie voor Koninkrijkrelaties wil nu een beknopt, maar goed beeld krijgen van de mogelijkheden voor de agrarische productie in Caribisch Nederland, inclusief de visserij). 
Doelstelling van deze studie is om op basis van bestaande kennis de huidige stand van zaken en ontwikkelmogelijkheden voor de agrarische en visserijsector te beschrijven voor Caribisch Nederland.

\subsection{Vraagstelling}

De commissie wenst antwoord te krijgen op de volgende vraag:

- Hoe is de agrarische productie in Caribisch Nederland geregeld en wat zijn de mogelijkheden voor verdere ontwikkeling?

Daarbij worden de volgende subvragen gesteld:

- Wat zijn de kritische succesfactoren om in het bijzonder de eigen voedselvoorziening en wellicht zelfs de export van agrarische producten substantieel in gunstige zin te beïnvloeden?

- Welke lessen kunnen worden getrokken uit de initiatieven die tot dusverre zijn ontwikkeld?

- Is een expertanalyse te geven met betrekking tot de vraag welke agrarische kansen er zijn per eiland? En hoe dat op hoofdlijnen gerealiseerd zou kunnen worden?

\subsection{Werkwijze}

Bestaande kennis, met name WUR-rapporten en -publicaties, beleidsdocumenten en diverse private initiatieven zijn bestudeerd en gebruikt om de onderzoeksvragen te beantwoorden. Een belangrijk vertrekpunt voor onze studie is de rapportage van een onderzoek in opdracht van het ministerie van Economische Zaken naar voedselzekerheid op Bonaire, Sint Eustatius en Saba (Bogaardt et al., 2015). In laatstgenoemde studie ging de aandacht vooral uit naar tuinbouw, en daarbinnen vooral de teelt van groente en fruit. Voor dierlijke producten en voor de visserij bestaat er geen duidelijk vertrekpunt. In het kader van het Plattelandsontwikkelingsproject Bonaire 2014-2019 (POP Bonaire) zijn voor Bonaire verschillende vee en/of veevoederinitiatieven ondernomen. Daarop aansluitend zijn studies geraadpleegd die vanuit Wageningen University \& Research zijn verricht (Neijenhuis et al., 2015, Bos \& Nijenhuis, 2018). Voor Sint Eustatius werd het agrarisch ontwikkelingsplan nader bestudeerd (DLG, 2011).

Voor Saba is er ten opzichte van de andere twee eilanden het minst gedocumenteerd over activiteiten in landbouw en veeteelt. Wel is relatief veel bekend over de visserij waarvoor vanaf 2012 structureel data wordt verzameld en waarvoor verschillende (WUR)-rapporten beschikbaar zijn. Als vertrekpunt voor de agrarische sector van Saba werden vooral drie inventariserende bronnen geraadpleegd (DLG 2012, Bogaardt et al., 2015, Briene et al., 2019).

Conceptantwoorden op de in 1.1 gestelde vragen zijn getoetst aan de mening van lokale ervaringsdeskundigen. Gezien het beschikbare budget en beperkte tijdspad waren bezoeken aan Bonaire, Sint Eustatius en Saba niet voorzien en is volstaan met commentaar en aanvullingen op een concept-tekst ontvangen van de volgende experts:

- Bonaire- Jan Jaap van Almenkerk, Sherwin Pourier (agrarische consultants), Olaf Creutzberg, Maurice Adriaens (interim-hoofd Dienst LVV);

- Sint Eustatius- Gershon Lopes (hoofd Dienst LVV), Dr. Erik Boman (directeur STENAPA);

- Saba- Drs. Menno van der Velde (hoofdambtenaar).

Het onderzoeksteam beschrijft eerst de huidige voedselproductie op de eilanden Bonaire, Sint Eustatius en Saba. Daarna brengt het de meer generieke factoren in kaart die bepalend zijn voor de ontwikkelingsmogelijkheden. Een beschrijving volgt van wat voor initiatieven er tot nog toe geweest zijn om voedselproductie verder te ontwikkelen en wat daaruit te leren valt. Vervolgens wordt ingezoomd op drie specifieke sectoren waar afgelopen jaren verschillende onderzoeken en initiatieven op gericht waren, namelijk de geitenhouderij (vleesproductie), innovatieve systemen voor groenteproductie en als derde de visserij. Dit inzoomen is om lessen te kunnen trekken over wat werkt en wat niet. Tenslotte beschrijft het projectteam hoe, op basis van het voorgaande, de geïdentificeerde kansen op hoofdlijnen gerealiseerd kunnen worden. 


\section{Beschrijving huidige voedselproductie}

Voor zover na te gaan zijn er geen officiële cijfers over de totale omvang van de voedselproductie per eiland over de tijd. Er zijn maar enkele professionele fulltime voedselproducenten. De meeste bedrijven die voedsel produceren in de Nederlandse Cariben zijn eenmansbedrijven met vooral neveninkomsten. Deze neveninkomsten zijn vaak gerelateerd aan het toerisme, bijvoorbeeld de verkoop van struisvogelbiefstuk of tilapia uit eigen vijver. Deze bedrijven hebben dus weliswaar een focus op een bepaalde agrarische activiteit, maar deze agrarische activiteiten zijn momenteel meestal niet grootschalig of winstgevend genoeg om als hoofdbron van inkomsten te kunnen dienen. De grote uitzondering daarop is de visserijsector op Saba die zich richt op kostbare voedselsoorten voor export en waarbij de betrokken vissers goed verdienen en tot de boven-middenklasse van het eiland behoren.

\section{Vlees}

Extensieve veeteelt op basis van onbeheerd loslopend vee is de overheersende agrarische activiteit op de eilanden. Op de drie eilanden betreft dit vooral geiten en op Sint Eustatius ook koeien. De vleesproductie die hieraan gerelateerd is, is met name voor lokaal gebruik. Dit systeem leidt door onbeheerste begrazing en betreding tot erosie, en drukt daarmee een zwaar stempel op andere agrarische sectoren en initiatieven. Door deze erosie is er ook een negatieve invloed op de kwaliteit van natuurterreinen (verlies van habitats) en via sedimentatie van geërodeerd materiaal op de koraalriffen.

Deze extensieve vorm van vleesproductie verschilt nauwelijks van het systeem dat ingesteld werd in de 16 de eeuw toen Juan de Ampués de Benedenwindse eilanden beheerde met een encomiendasysteem (stukken land die aan Spaanse kolonisten werden toegekend) onder Spaans bewind (Hartog, 1957). Tijdens de daaropvolgende Nederlandse koloniale periode werd het plantagesysteem ingevoerd. Daarbij werd door middel van diverse vormen van afrastering de teelt van economische gewassen (o.a. maïs) naast eenvoudig kudde- en weidebeheer mogelijk. Echter, na het verdwijnen van de laatste van oorsprong koloniale plantagebedrijven in het midden van de 20ste eeuw, keerde men terug tot het systeem van het deels onbeheerd houden van loslopende kuddes vee.

Op Bonaire is één professioneel pluimveebedrijf (Punta Blanku Farms N.V.) dat eieren (van 27.000 hennen) en vleeskuikens produceert. $\mathrm{Er}$ is ook een pluimveehouderij in Rincon met meer dan 3.000 hennen die zich uitbreidt. Dit bedrijf produceert ook eieren en vlees. Geiten worden overwegend nietprofessioneel gehouden en vaak voor eigen gebruik geslacht. Op één kleinschalig bedrijf worden geiten gemolken (Aletta's Goat Farm). Op sommige kunuku's (landelijke gebieden, buiten de bebouwde kom) wordt ook een enkele koe of varken gehouden. Op Bonaire is men bezig met de renovatie van het slachthuis (zie Hoofdstuk 4). Het slachthuis is nu zeer basaal ingericht voor de slacht van geiten, schapen en een enkel varken en rund (zie Tabel 1.).

Op Sint Eustatius is een pluimveebedrijf met 500 slachtkippen en 750 legkippen (Rijksbegroting, 2020). Vanwege de hoge kosten van geïmporteerd voer is continuïteit van dit bedrijf afhankelijk van subsidie of een andere vorm van overheidssteun (G. Lopes, pers. comm.). Ook op dit eiland worden extensief gehouden geiten en koeien geslacht in een lokaal slachthuis (zie Tabel 1.).

De export van vlees (met name rundvlees) van Sint Eustatius naar buureilanden betrof 1.500 tot $2.500 \mathrm{~kg}$ per maand voordat de Covid-19 beperkingen begonnen te spelen (G. Lopes, pers. comm.). $\mathrm{Er}$ is een duidelijke wens om de vleesproductie op Sint Eustatius te verhogen (Koninkrijk.nu, 2020).

Op Saba is geen slachthuis en alle slacht (van geiten en geïmporteerde runderen) vindt informeel plaats (DLG 2012, M. van der Velde, pers. comm.). Op een enkele uitzondering na worden alleen geiten gehouden; deze lopen vooral los (DLG, 2012). Tot de jaren 60 van de vorige eeuw werd het vee achter omheiningen gehouden omdat loslopend vee veel schade toebracht aan de vele kleine "back yards", veldjes voor tuinbouw die toen nog actief bewerkt werden. Sindsdien is er geen controle 
meer op de naleving van de wet die loslopend vee verbiedt, en is tuinbouw duur en moeilijk omdat alles afgerasterd moet worden en geiten zeer moeilijk buiten de aanplant te houden zijn (DLG, 2012). Aangezien door Covid-19 beperkingen er op Saba groeiende behoefte is om meer groenten en kruiden in eigen tuin te kweken, staat het geitenprobleem recent ook weer op de agenda (zie paragraaf 4.2).

Op Saba zijn drie kleinschalige pluimveehouderijen actief die de lokale markt van vooral verse eieren voorzien. Door de hoge prijzen van kippenvoer, dat volledig geïmporteerd wordt, zijn de eieren fors duurder dan de uit de VS geïmporteerde eieren, hetgeen een hogere afzet van lokaal geproduceerde eieren belemmert (M. van der Velde, pers. comm.).

Tabel 1 Gemiddeld aantal geregistreerde slachtingen per jaar per diersoort op Bonaire (gemiddelde van 2012-2018) en Sint Eustatius (gemiddelde van 2018 en eerste helft 2019). (Bron: Y. de Vries en O. Creutzberg, pers. comm).

\begin{tabular}{lrr} 
& Bonaire & \multicolumn{2}{c}{ Sint Eustatius } \\
Runderen & 4 & 39 \\
\hline Varkens & 132 & 41 \\
\hline Schapen & 294 & 165 \\
\hline Geiten & 1509 & 269 \\
\hline totaal & 1938 & 513 \\
\hline
\end{tabular}

\section{Voedingsgewassen}

Slechts op kleine schaal verbouwen de eilanders voedingsgewassen op akkers die niet geïrrigeerd worden. Deze teelten op akkers leveren producten die, tegen lagere dan de reële lokale productiekosten, kunnen worden geïmporteerd uit landen waar deze teelten grootschalig en daardoor goedkoper plaatsvinden. De huidige lokale agrarische infrastructuur is te kleinschalig of te gefragmenteerd om met akkerbouwgewassen te kunnen concurreren met het buitenland.

Op Bonaire wordt het graangewas sorghum het meest op akkers verbouwd. Maïs, bonen en pinda's hebben meer water nodig en vindt men vooral in tuinen waar makkelijker water gegeven kan worden. De professionele tuinbouw op Bonaire heeft een impuls gekregen op de sociale werkplaats van Stichting Krusada waar als onderdeel van de dagbesteding, groenten geteeld worden in kassen (Krusada Green, http://www.fundashonkrusada.org). In de kassen worden verschillende hoogsalderende gewassen geteeld zoals spinazie, paksoi en rucola, en verschillende kruiden (basilicum, munt) (Bogaardt et al, 2015). Begin 2019 is het bedrijf Bon Tera met een kas van 0,5 ha gestart. Op basis van ervaring opgedaan bij Krusada verbouwt dit bedrijf verschillende soorten sla, spinazie, komkommers, paprika's, yambo, kousenband, microgreens en verschillende kruiden en verkoopt deze producten aan horeca, supermarkten en rechtstreeks aan particulieren.

Verschillende lokale ondernemers zijn recent begonnen met het verbouwen van groenten, o.a. middels het hydroponics systeem (zie Hoofdstuk 4). Deels zijn dit nog pilots, waarin bijvoorbeeld een combinatie van innovatieve groetenteelt met visteelt (tilapia) plaatsvindt.

Op Sint Eustatius is de agrarische bedrijvigheid op het gebied van groenteteelt in afgelopen jaren toegenomen (G. Lopes, pers. comm.). Van oudsher teelt het bedrijf Hazel's Plantation o.a. pepers en tomaten. Inmiddels zijn er ook vijf andere telers actief die gezamenlijk op kleine schaal groenten en gewassen als bananen, zoete aardappelen, pinda's en pompoenen verbouwen. Deze agrarische bedrijvigheid op het eiland vindt allemaal plaats vlak bij het station van de dienst Landbouw, Veeteelt en Visserij (Openbaar Lichaam) op de "cultuurvlakte" vlak bij de luchthaven. Alle telers maken gebruik van het water uit één put, namelijk de Concordia Well.

"Stichting Made in Statia" is een initiatief om Sint Eustatius wat betreft groente- en fruitproductie meer zelfvoorzienend te maken. Dit initiatief is gestart in 2017 met steun van dezelfde dienst Landbouw, Veeteelt en Visserij en heeft onder andere als doel plantmateriaal op te kweken dat uitgeleverd wordt aan de lokale telers. De stichting helpt deze telers vervolgens met de afzet van de 
geproduceerde groenten en fruit. Hoewel er veel enthousiasme is op het eiland voor dit project, worden door lokaal betrokkenen ook aanloopproblemen gemeld, met name ten aanzien van de watervoorziening, de beschikbaarheid van personeel en in bijzonder het daarbij betrekken van jongeren (https://caribischnetwerk.ntr.nl/2018/12/08/agriculturele-centrum-van-statia-moet-eilandzelfvoorzienender-maken/).

Op Saba zijn momenteel twee tuinbouwprojecten, de Organoponics Garden van Saba Reach Foundation in The Level, en sinds 2017 het tuinbouwproject van de Agricultural Station van het Openbaar lichaam. De Organoponics Garden is een sociale werkplaats waar op kleine schaal verschillende groenten worden verbouwd. Organoponics staat hier voor "organisch bio-intensief tuinieren" in de grond (https://caribischnetwerk.ntr.nl/2014/05/04/saba-wil-zeggenschap-overfondsen-lokale-landbouw/). Lokale consumenten worden nauw betrokken bij de teelten, denken bijvoorbeeld mee over wat gezaaid of geplant wordt. De tuin richt zich vooral op steun aan lokale telers en heeft daarnaast sociale en educatieve doelstellingen. De groenten worden wekelijks verkocht in een kraampje in Windward Side. Het tweede tuinbouwproject, dat gelegen is tussen Windwardside en het vliegveld, wil een demonstratie geven van de groenten die op Saba geproduceerd kunnen worden. Er is onlangs een plan gemaakt voor tuinbouw in kassen op Rendez Vous. Deze locatie wordt momenteel bouwrijp gemaakt.

Op Saba zijn, vergeleken met de andere twee eilanden, relatief veel bewoners die eigen groente verbouwen (Figuur 2). Op dit eiland liggen de dorpen hoger boven zeeniveau waardoor in de tuinen meer neerslag valt en daardoor tegelijk meer mogelijkheden zijn om eigen groenten en fruit te telen. Traditioneel belangrijke gewassen zijn zoete aardappelen, maniok, bonen, bananen, papaja, ananas, pompoenen en verschillende boomvruchten zoals mango, zuurzak en guave. Deze worden op kleine schaal geteeld. Van de drie eilanden heeft Saba de traditie van kleinschalige tuinbouw en groenteteelt beter weten te behouden dan Bonaire en Sint Eustatius.

\section{Luxe agro-producten}

Op bescheiden schaal zijn er met name op Bonaire teelten van gewassen die grondstoffen leveren voor luxe producten met relatief hoge economisch waarde of potentieel. Het gaat dan vooral om Aloë vera. Inhoudstoffen van deze plant wordt met name gebruikt voor cosmetica en wondverzorging. Het bedrijf Onima op Bonaire verbouwde Aloë vera (www.onima-aloe.info/nl/home.html). Dit bedrijf ligt echter stil wegens ziekte van de eigenaar en het is onzeker wat hier in de toekomst gaat gebeuren. De intentie om niet alleen Aloë vera zelf te verbouwen maar ook op andere kunuku's dit gewas te oogsten, is niet van de grond gekomen. Om een goede productie te halen bij de Aloë vera teelt, is men van mening dat irrigatie ter aanvulling van natuurlijke neerslag nodig. Op de kunuku van Onima is irrigatie mogelijk door aansluiting op het waternet. Veel andere kunuku's liggen te ver van het waternet en zijn geheel afhankelijk van regenwater.

Op Bonaire worden ook cactussen op kleine schaal geoogst voor het stoken van likeuren (https://www.cadushy.com/). Vanwege het toerisme op de eilanden heeft teelt van deze "speciality" gewassen waarschijnlijk een groter potentieel dan op dit moment wordt gerealiseerd.

De mogelijkheden voor uitbreiding van de Aloë vera teelt en cactusteelt voor productie van luxe producten met hoge marktwaarde (per kilo) en/of voor gebruik in de speciale cosmetica, dienen nader onderzocht te worden.

\footnotetext{
Visserij

Voor de visserijsector van Caribisch Nederland zijn er wel recente statistieken. De kreeftenproductie van Saba en Sint Eustatius is bijna geheel voor export naar Sint Maarten evenals de productie van de rode landkrab Gecarcinus ruricola op Saba. De overige visproductie (van vinvissoorten) is grotendeels voor lokale consumptie. Dit betreft de vangst van pelagische vis (van open zee), koraalrifvis (bijvangst) en snappers (een grote baarsachtige) zoals plaatsvindt door middel van kreeft- en visfuiken op de Saba Bank. Recent onderzoek heeft aangetoond dat deze visserijen met kreeft- en visfuiken, in gezonde staat lijken te verkeren en het advies is dan ook dat een voorzichtige expansie van zowel de kreeftenvangst als de snapper-vangst geoorloofd lijken (Debrot \& De Graaf, 2018a).
} 
Met uitzondering van de kreeft en snapper vangst van de Saba Bank en de kroonslak van de Saba Bank en rond Sint Eustatius, kan de koraalrif-visserij grotendeels worden beschouwd als overbevissing (Debrot \& De Graaf, 2018a). Dit geldt mogelijk ook voor de visserij rond Sint Eustatius (Graaf et al., 2015). Dit komt mede omdat de traditionele visserij zich vooral op bevissingsgevoelige toppredatoren heeft gericht zoals de zeebaarzen (groupers en snappers). Deze toppredatoren behelzen slechts een klein maar belangrijk deel van de voedselpiramide van het koraalrifsysteem. Door de visserij vooral op dit specifieke deel van het ecosysteem te richten zijn verschillende vissoorten nagenoeg weggevist waardoor sommige zelfs als bedreigde soorten moeten worden aangemerkt (Debrot \& De Graaf, 2018a). Door de visserij te transformeren naar een visserij waar de focus lager in het voedselweb ligt, is het mogelijk om tegelijk de netto vangst te vergroten en het netto negatieve effect op ecosysteem te verminderen.

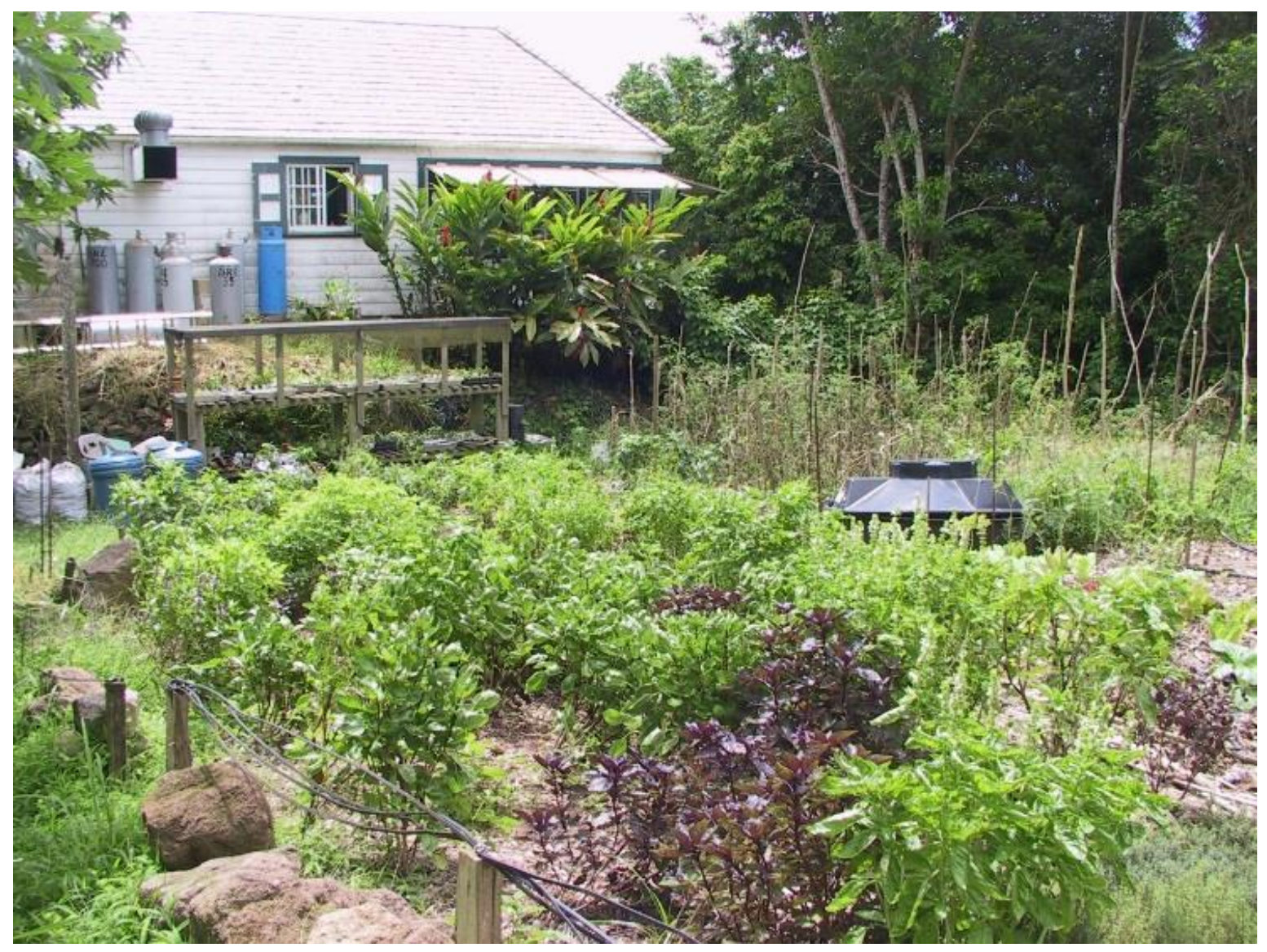

Figuur 2 Typische kleine kruidentuin op Saba voor de kweek van groente en fruit voor eigen gebruik (Foto: Dolfi Debrot). 


\section{Factoren die bepalend zijn voor de kansen van landbouw}

Dit hoofdstuk beschrijft de meer generieke factoren die bepalend zijn voor de ontwikkelingsmogelijkheden van voedselproductie in Caribisch Nederland.

\subsection{Waterbeschikbaarheid en watergebruik}

Zonder goede beschikbaarheid van water zijn de mogelijkheden voor duurzame groei van landbouw of veeteelt zeer beperkt. Het tekort aan zoetwater wordt door lokale landbouwkundige experts op zowel Bonaire als Sint Eustatius ervaren als de grootste beperking op de landbouw (M. Adriaens en G. Lopes, pers. comm.). Uiteraard dient de bodem voldoende vruchtbaar te zijn. Als een lage bodemvruchtbaarheid feitelijk toch de belangrijkste groeibeperkende factor zou zijn, leidt een betere waterbeschikbaarheid niet direct tot een beoogde productietoename. Dit geldt voor diverse aride (droge) gebieden in de wereld. Er zijn echter zo ver na te gaan is, geen gepubliceerde bemestingsproeven die inzicht kunnen geven over in hoeverre op de drie eilanden de beschikbaarheid van plantenvoedingstoffen primair de plantaardige productie beperkt. Wel is er op de eilanden brede praktijkervaring dat irrigatie in combinatie met bemesting betere gewasgroei mogelijk maakt.

Regenwater is over het algemeen geschikt voor gebruik in de landbouw. Het grondwater op de eilanden heeft vaak een hoog zoutgehalte door een hoge verdamping uit de bodem (evaporatie) en vegetatie (transpiratie). Daarbij is de informatie over het grondwater veelal gedateerd. De geringe beschikbaarheid en kwaliteit van grondwater op de eilanden (Grontmij \& Sogreah, 1968; Rowbottom \& Winkel, 1979; Borst \& De Haas, 2005; Sambeek et al., 2000) zal echter in de afgelopen decennia waarschijnlijk niet verbeterd zijn. Zover bekend zijn daartoe geen grootschalige maatregelen genomen.

Hoewel dus geschikt voor landbouw, is regenwater maar beperkt beschikbaar. Dit komt hetzij door een hoge verdamping (vooral op Bonaire), hetzij door gebrek aan een goede infrastructuur om het regenwater op te vangen en beschikbaar te maken voor gewassen (Slijkerman et al., 2019). Regenval is daarnaast variabel en onvoorspelbaar. Zo is op Bonaire de regenval gemiddeld 500 $\mathrm{mm}$ per jaar maar er zijn jaren bij met minder dan $200 \mathrm{~mm}$ en meer dan $1600 \mathrm{~mm}$ per jaar (Openbaar Lichaam Bonaire, 2014). Op Sint Eustatius en Saba valt meer neerslag, gemiddeld 985 mm en $760 \mathrm{~mm}$ per jaar. Beide Bovenwindse eilanden kennen een tropisch moessonklimaat, met een regentijd van augustus tot en met december en een (relatief) droge tijd van januari tot en met april (KNMI, 2017). Ook op deze twee eilanden verschilt de hoeveelheid neerslag van jaar tot jaar.

Een deel van de neerslag spoelt door het lokale reliëf en geringe infiltratiemogelijkheden van het eiland af. Opvang van regenwater met dammen en bassins of tanki's zoals dat vroeger de gewoonte was op Bonaire en Sint Eustatius, is van groot belang (Debrot, 2004b, c). Op Saba is dergelijke infrastructuur niet mogelijk vanwege de steile hellingen van het eiland. Wateropvang is daardoor historisch beperkt gebleven tot opvang vanaf daken voor opslag in een cisterne voor gebruik als drinkwater. Saba heeft, door een losse vulkanische bodem en permeabele diepere lagen, geen grondwaterspiegel. Er zijn dus geen bruikbare zoetwaterbronnen of putten. De landbouw op Saba is daarom helemaal afhankelijk van regenwater of ontzilt water dat met kleine trucks vervoerd moet worden. Dit water wordt geleverd voor de prijs van US\$30 per kubieke meter (M. van der Velde, pers. comm.).

Op Bonaire zijn er putten, vooral verbonden aan grotten (karst) die zijn uitgespoeld in de kalksteenbodems van het eiland door percolerend regenwater (Wagenaar-Hummelink, 1979; Debrot, 
2004a). Op dit eiland is een aantal waterputten en dammen hersteld door de lokale overheid (bonaire.nu/2017/04/11/overheid-herstelt-vier-waterputten/). Het water uit de putten is in principe alleen bestemd voor veehouders om hun dieren te drenken. Op een paar putten na (bijvoorbeeld de lokaal bekende Dos Pos, vertaald de bron van Fontein) is het water dat uit de putten komt, brak. Dit brakke water lijkt echter wel geschikt als drinkwater voor geiten

(bonaire.nu/2019/05/07/verspilling-en-misbruik-van-putwater/). Volgens M. Adriaens (pers. comm.), interim-directeur van de Landbouw, Veeteelt en Visserij van Bonaire, is een waterplan (zie ook Slijkerman et al., 2019) voor het eiland essentieel.

Gezuiverd afvalwater is ook geschikt als water voor landbouwgewassen. De mogelijkheden hiertoe zijn tot nog toe echter beperkt. Op Bonaire wordt afvalwater gezuiverd door het Water- en Energiebedrijf Bonaire N.V. (WEB). Drinkwater wordt voor een gesubsidieerde prijs naar de kunuku's gebracht door WEB. Dit drinkwater is voor menselijke consumptie en voor het vee. WEB kan maar kleine hoeveelheden water leveren met trucks. Er kan niet voldoende worden geleverd voor het irrigeren van gewassen (J.J. van Almenkerk, pers. comm.). Het probleem is dat vervoer van water met een vrachtwagen over slechte wegen naar de kunuku's duur is. Volgens WEB is de reële kostprijs US\$18/kuub.

De afvalwaterzuivering van WEB bevindt zich op het terrein van de dienst Landbouw, Veeteelt en Visserij. Het irrigatiewater is in het kader van het Plattelandsontwikkelingsprogramma (POP) korte tijd op dit terrein ingezet voor de productie van veevoer voor geiten (zie ook Hoofdstuk 4).

\section{Een ontwikkeling om beschikbaarheid van irrigatiewater te vergroten is het ontzilten van zeewater; zie hiervoor Hoofdstuk 4.}

Op Sint Eustatius wordt de beperkte beschikbaarheid van zoetwater voor irrigatie ook gezien als een belangrijke bottleneck voor de landbouw en veeteelt (G. Lopes, pers. comm.). Daarom heeft de dienst Landbouw, Veeteelt en Visserij van het eiland het initiatief genomen om een opvangbassin uit te graven dat met plastic wordt bekleed. Dit is bedoeld om het water van het zonnepanelen-park op te vangen en beschikbaar te stellen aan de tuinders (G. Lopes, pers. comm.). Deze dienst gaat nóg een bassin maken voor opslag van regenwater wat een expansie van landbouw mogelijk zal maken. Daarnaast is onderhoud en herstel van putten noodzakelijk. Twee putten in de streek Zeelandia zijn recent schoongemaakt en is er een hoger gelegen reservoir gebouwd om via de zwaartekracht de boeren van irrigatiewater te kunnen voorzien. Omdat daar geen stroomvoorziening aanwezig is, is men van plan om een paar dompelpompen op zonne-energie te kopen om het water uit de putten in het reservoir te pompen (G. Lopes, pers. comm.).

Naast irrigatie zou het ook een optie kunnen zijn om teeltsystemen te ontwikkelen met gewassen die minder water nodig hebben. Met droogtetolerante teelten is reeds enige ervaring op Bonaire in de vorm van de teelt van schijfcactus als veevoeder. Uit onderzoek van POP Bonaire blijkt dat schijfcactussen zonder doornen geschikt zijn als geitenvoer (Köster, 2015). Echter, probleem blijkt dat op het eiland deze schijfcactus met alleen regenwater als neerslag slechts marginaal groeit. Dus ook hier is enige irrigatie nodig om voldoende veevoer te kunnen produceren. Daar er geen irrigatiewater is op de kunuku's, is dit onderzoek stopgezet.

Een andere mogelijkheid zou zijn om zouttolerante gewassen te telen die kunnen gedijen op brakwater. Hiervoor is recent een project gestart op Bonaire met de gewassen ijskruid en Aloë vera (zie paragraaf 4.1). Quinoa is een gewas (pseudo-graan) uit Zuid-Amerika dat als 'superfood' bekend staat, en waar bij WUR ook veel kennis wordt ontwikkeld met betrekking tot zouttolerante variëteiten, en zelfs de teelt in Nederland (https://www.wur.nl/nl/artikel/10-vragen-enantwoorden-over-quinoa-telen-in-Nederland.htm). Het telen van quinoa zou ook een optie kunnen zijn, maar zo ver de auteurs bekend is daar op Bonaire nog geen ervaring mee.

Tenslotte kan verdamping in een teelt beperkt worden door gecontroleerd telen in kassen. Met nieuwe technologie (hydroponics) kan de efficiëntie van watergebruik om gewassen te telen in kassen, verder worden verhoogd. Een initiatief hiertoe wordt nader beschreven in paragraaf 4.3. 


\subsection{Beschikbaarheid van land en geschiktheid van de bodem}

Een volledig en recent overzicht van de geschiktheid van de bodem voor landbouw op elk van de drie eilanden ontbreekt. Voor de indeling van grondsoorten op Bonaire wordt vaak verwezen naar de oude kaarten van Grontmij \& Sogreah (1968). Bodemkaarten van Sint Eustatius en Saba zijn nog ouder (Veenenbos, 1955).

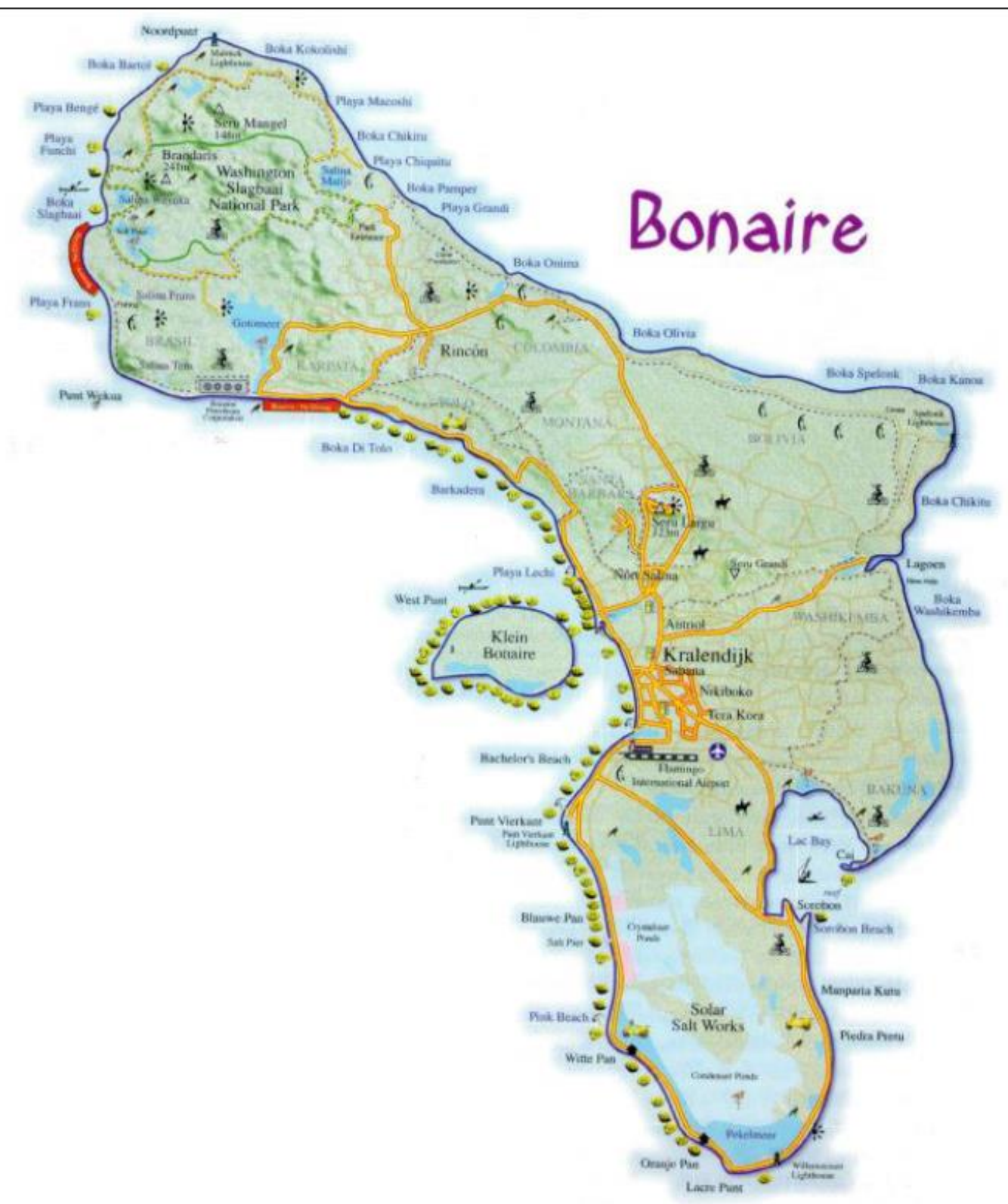

Figuur 3 Kaart van Bonaire (Bron: Openbaar Lichaam Bonaire, 2018).

Drie gebieden op Bonaire hebben officieel de bestemming agrarisch-kunuku: Rincon en omgeving, Tras Montaña en het gebied ten oosten van Kralendijk bekend als Bara di Karta (Figuur 3). Samen beslaan deze gebieden ongeveer 7.000 ha oftewel $25 \%$ van het oppervlak van het eiland (Openbaar Lichaam Bonaire, 2014).

Op Sint Eustatius is de bodem (vooral van de "Cultuurvlakte") weinig steenachtig en in het algemeen geschikt voor landbouwproductie. 


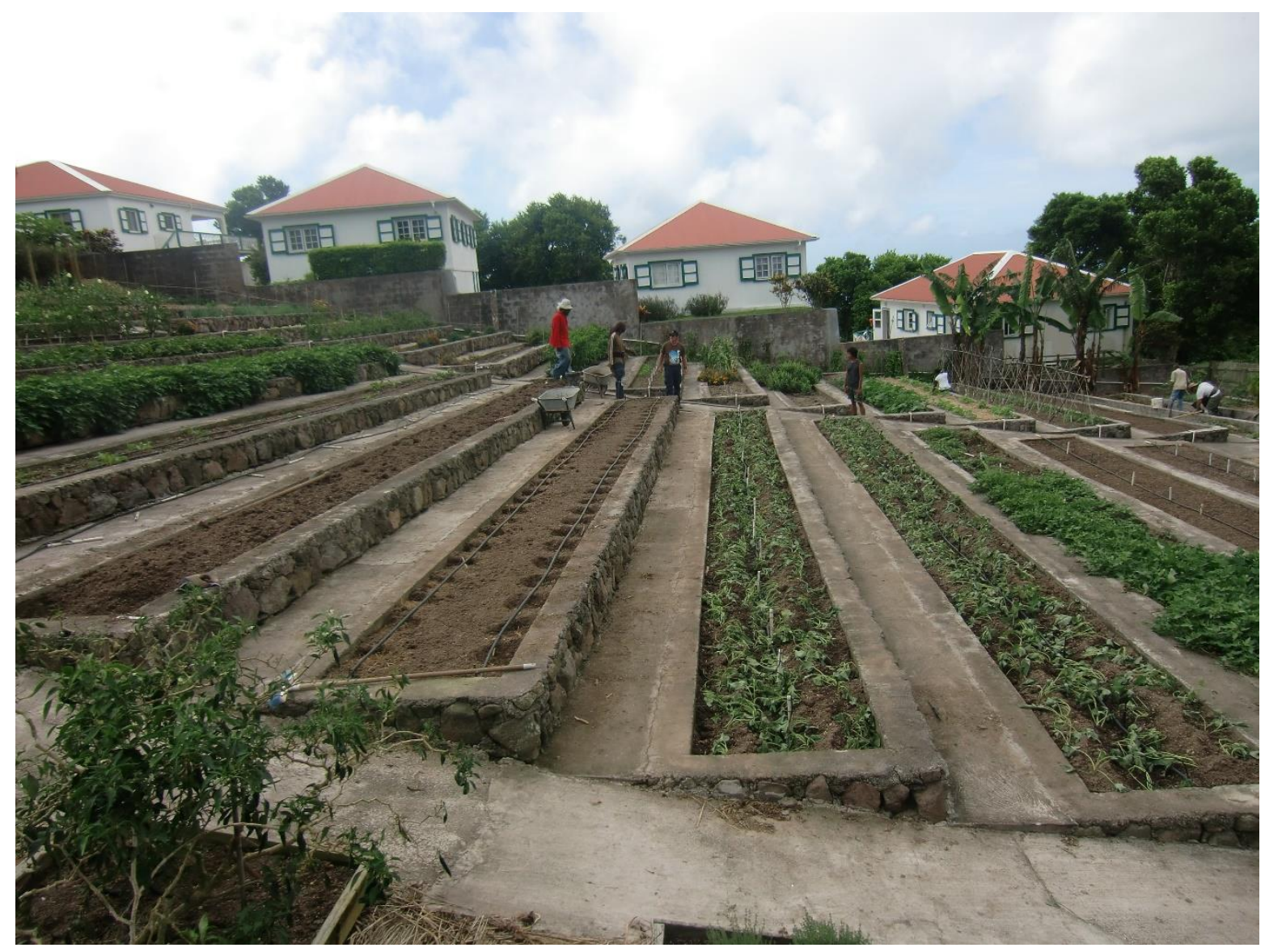

Figuur 4 Terrasbouw voor de productie van groenten voor de lokale markt op Saba (Foto: Dolfi Debrot).

De geschiktheid van de bodem voor gemechaniseerde landbouwproductie is op Saba nihil door gebrek aan grotere stukken effen en steenvrije grond. De steile en zeer rotsachtige bodems, typerend voor Saba, betekenen dat landbouwproductie grotendeels kleinschalig en handmatig is, bijvoorbeeld door terrasbouw (Figuur 4). Daarnaast is een complicerende factor dat alle grond in particuliere handen is en vaak nog in onverdeelde boedels.

Een bijkomend probleem op met name Bonaire en Sint Eustatius is dat soms het te bebouwen stuk grond eerst geheel wordt 'schoon geveegd' met behulp van een bulldozer, en daarna geploegd voor het inzaaien. Dit maakt de grond extra gevoelig voor erosie, zeker als de grond een tijd onbedekt blijft door beperkte waterbeschikbaarheid. Erosie veroorzaakt degradatie van de landbouwgrond en bedreigt bij afspoeling naar zee het koraal (Figuur 1).

\subsection{Ondersteuning door lokale overheden}

Op elk van de drie eilanden heeft de lokale overheid een ondersteunende taak, gezien enerzijds het belang dat in een vitale lokale landbouw gesteld wordt en anderzijds de knelpunten waarmee een teler te maken krijgt om duurzaam en rendabel voedsel te produceren. De invulling van deze taak van de lokale overheid op de eilanden is echter beperkt. Het is aannemelijk dat deze ondersteuning nog niet optimaal is voor goede ontwikkelingsmogelijkheden van de landbouw. Bronnen die dit aangeven (zie hieronder) zijn echter deels verouderd.

Het ministerie van LNV heeft op de eilanden alleen structurele ondersteunende taken op het gebied van natuur- en milieubeheer. Deze nationale betrokkenheid op gebied van natuur en milieu is op basis van internationale verdragen. 
Op Bonaire biedt de Dienst Landbouw, Veeteelt en Visserij (LVV) beperkte ondersteuning aan de landbouwers. Zo biedt de dienst rasgeiten en schapen te koop aan of rammen die geleend kunnen worden om te dekken en zo het slachtvee te helpen verder te fokken. Zaden, kunstmest en gewasbeschermingsmiddelen worden ook verkocht. De verkoop van teeltbenodigdheden zullen komende jaren meer en meer ondergebracht worden bij de landbouwcoöperatie KRIABON (M. Adriaens, pers. comm.). Ook heeft LVV inheemse boompjes voor de verkoop en voor de openbare plantsoenen maar het meeste van deze dienstverlening is overgenomen door de Stichting Echo (http://www.echobonaire.org/) die zich ook bezig houdt met herbebossing.

Op dit ogenblik wordt de dienst LVV gereorganiseerd. Hierbij is het de bedoeling LVV om te bouwen tot een kenniscentrum waar op het terrein (50 ha groot met goede teelaarde) private ondernemers landbouw kunnen bedrijven. Dit wordt gemodelleerd naar het concept eerder toegepast in het Soltuna project te Groot Piscadera op Curaçao (M. Adriaens, interim directeur LVV, pers. comm.; Tweede Kamer der Staten-Generaal. 2020. 33845 Interparlementair Koninkrijksoverleg (antwoord 42) https://app.1848.nl/static/pdf/15/38/15387d7e9c6e3949d362200b13797edf74288787.pdf).

Op Sint Eustatius biedt de dienst LVV ook beperkte ondersteuning aan de landbouwers wat betreft toelevering van benodigdheden voor teelt en afzet.

Voor Saba identificeert een 8 jaar oude bron (DLG, 2012) gebrek aan voldoende infrastructurele ondersteuning (zoals lichte machines voor landbewerking, zaden, overige landbouw benodigdheden) als een belangrijke beperkende factor voor een toename van voedselproductie. In hoeverre dit gebrek nu nog speelt, is niet gedocumenteerd. Op dit eiland biedt de Agricultural Station van Dienst LVV vanwege de kleinschaligheid echter waarschijnlijk nog steeds slechts beperkte lokale ondersteuning voor land- en tuinbouw. Twee in het oog springende programma's van deze Dienst betreffen de bestrijding van overlast veroorzakende muggen (vanwege gezondheidsrisico's) en ratten (Smith et al., 2014). Ratten zijn talrijk op Saba, vooral in gebieden die het meest geschikt zijn voor tuinbouw. Zij beschadigen daar een deel van de producten voor deze geoogst worden (Debrot et al., 2014) (Figuur 5).

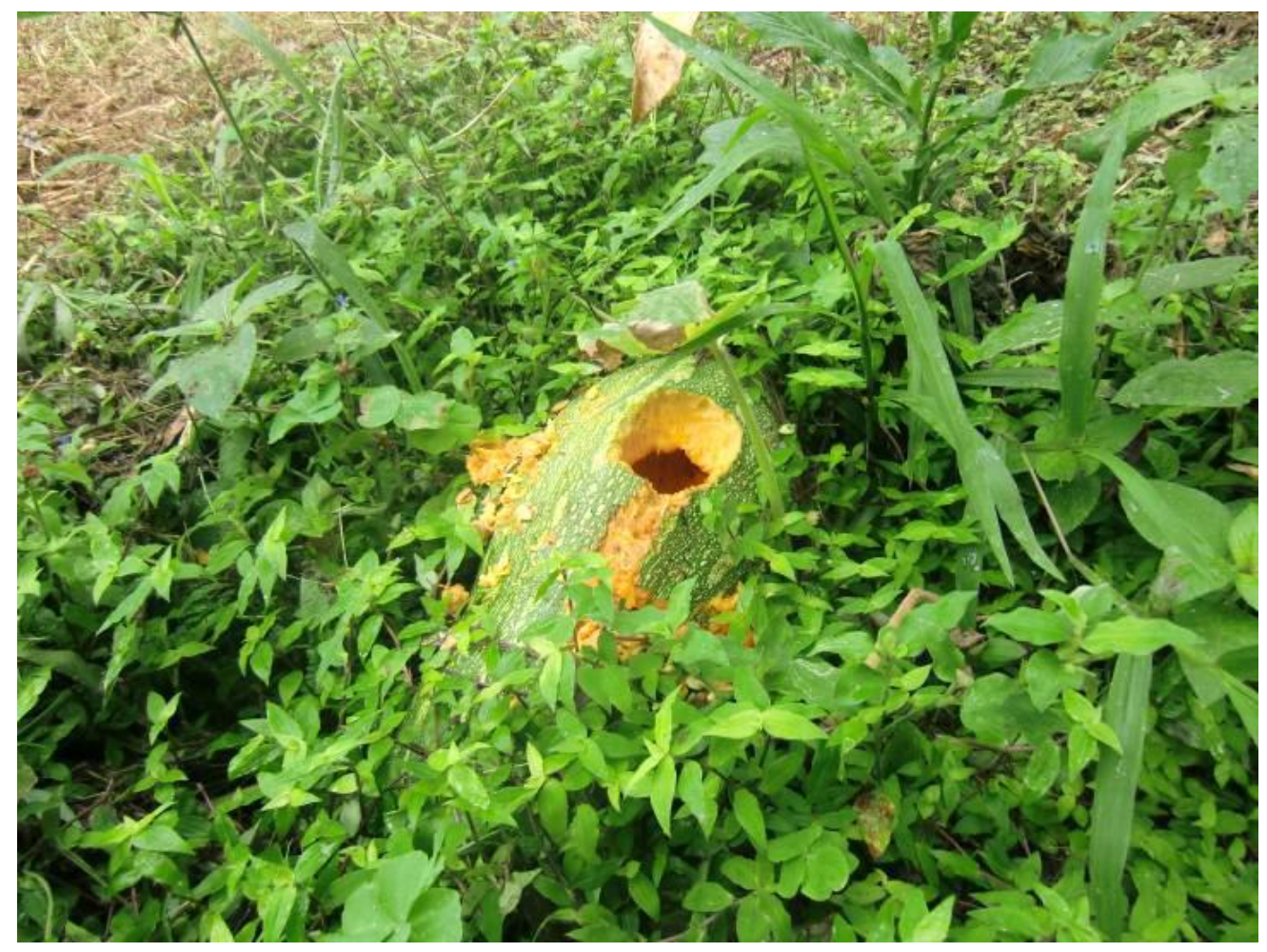

Figuur 5 Schade door ratten bij de teelt van groenten op Saba (Foto: Dolfi Debrot). 


\subsection{Conflicterende belangen (begrazing, toerisme)}

Loslopend vee, waaronder vooral de geiten, conflicteert op alle drie de eilanden zowel met de teelt van gewassen door vraat, als met natuurbelangen door erosie en daardoor degradatie van natuurgebieden en koraalriffen. Onder dit extensieve productiesysteem van vlees profiteert in feite een kleine groep veehouders ten koste van een breder, algemeen belang. Het begrazen van publieke gronden (mondi) buiten de dorpen in de landelijke gebieden is daarmee een klassiek geval van de "tragedy of the commons" (Hardin, 1968): individuen die rationeel hun eigen belang nastreven, putten gezamenlijk een publieke hulpbron uit. De 'commons' kunnen alleen duurzaam functioneren bij een lage grazersdichtheid. Wil men de grazersdichtheid verhogen, zal men over moeten gaan naar een begrazingssysteem waarin de dieren zijn ingerasterd.

In het kader van deze studie werd geen gedetailleerd onderzoek gedaan naar conflicterende belangen tussen landbouw en recreatie. Deze studie geeft daarom geen compleet beeld in welke mate, er conflicterende belangen spelen tussen deze beide sectoren. De druk in het buitengebied om daar meer bungalows te bouwen of recreatiecentra aan te leggen, wordt steeds groter. Echter, de meeste ontwikkelingsdruk en grondspeculatie in verband met toeristische ontwikkeling vindt plaats in de gebieden langs de kust en niet in de drie, door de overheid aangewezen, tevens meest geschikte gebieden voor agrarische ontwikkeling (Achterland van Rincon, Bara di Karta en Tras Montaña) (Rijksoverheid, 2018). De kustgebieden worden grotendeels getypeerd door kalksteenbodems en zijn ongeschikt voor enige grondbewerking.

Er lijkt een vooralsnog conflicterende bepaling te zijn op het gebied van ruimtelijke ordening. Binnen de huidige kadernota grondbeleid is een probleem geslopen omdat daarin wordt aangegeven dat binnen de bestemming "kunuku" (buitengebied) geen agrarische activiteit mag plaatshebben die economische waarde oplevert. Dat is in tegenspraak met de plannen van Plattelandsontwikkelingsprogramma en het Plan van aanpak geprofessionaliseerde geitenhouderij, die uitgaan van economische ontwikkeling van het agrarisch gebied (M. Adriaens, pers. comm.).

\subsection{Regelgeving}

Een goede wet- en regelgeving (en handhaven daarvan) is belangrijk voor het op een veilige en duurzame wijze produceren van voedsel. Een aantal juridische zaken vereist ten aanzien van landbouw en grondgebruik nog verdere ontwikkeling.

Bonaire, Sint Eustatius en Saba hebben de juridische status van openbare lichamen, een met gemeenten vergelijkbare positie. Europese en Nederlandse regelgeving zijn niet van toepassing, behoudens uitzonderingen. Er is voor gekozen om de tot 10-10-2010 bestaande regelgeving van de Nederlandse Antillen in beginsel te handhaven. De Invoeringswet openbare lichamen biedt hiervoor de basis (zoek.officielebekendmakingen.nl/kst-34550-IV-Q.html). De Invoeringswet openbare lichamen Bonaire, Sint Eustatius en Saba heeft onder andere het toenmalige Burgerlijk Wetboek van de Nederlandse Antillen de status gegeven van Nederlandse wet voor Caribisch Nederland, onder de naam Burgerlijk Wetboek BES. Overzicht van de andere wetten die gelden op de die eilanden zijn te vinden via maxius. nl/wetten-bes.

\subsubsection{Grondwater Beheer}

Momenteel is er geen regelgeving om uitputting van het grondwater te voorkomen. Het is daarom aan te raden om grondwaterbeheer, gestoeld op een adequate regelgeving, op te zetten om te voorkomen dat iedereen een put gaat slaan en dat de putten op een nietduurzame wijze gebruikt worden. Door de aanhoudende droogte wordt het grondwater niet genoeg aangevuld met vers zoet water waardoor bij hoge onttrekking van putwater voor gebruik in de 
landbouw, de kans groot is dat het water nog brakker wordt of dat een put leeg getrokken wordt. Dit grondwaterbeheer zou onderdeel moeten zijn van een integraal zoetwaterplan (zie Hoofdstuk 5).

\subsubsection{Preventie en bestrijding van invasieve exotische soorten}

Import van groenten en fruit voor consumptie en ook de import van planten voor de hovenierssector, brengen het risico mee van het invoeren van invasieve exotische soorten, waaronder agrarische plagen. Er is een wettelijk kader voor fytosanitair beleid en regelgeving in de Invoeringswet BES (www.rijksdienstcn.com/landbouw-natuurvoedselkwaliteit/landbouw-tuinbouw-voedselkwaliteit). In hoeverre dit wettelijk kader voldoet om problemen in agrarische productiesystemen door invasieve exoten te voorkomen, is niet gedocumenteerd.

In het kader van deze regelgeving heeft de Dienst LVV van Sint Eustatius twee jaar intensief de recent aangekomen Afrikaanse Reuzenslak bestreden. Deze exoot vormt een plaag voor de groenteteelt (Debrot et al. 2016).

De praktijk op Saba is dat de douane geen controle uitoefent op de import van groenten en fruit. Er vindt alleen controle plaats of de eventuele verplichte algemene bestedingsbelasting (ABB) betaald is of niet (M. van der Velde, pers. comm.). In hoeverre er op Bonaire en Sint Eustatius een effectieve controle is op invoer van invasieve exotische soorten, is nog onduidelijk.

\subsubsection{Gewasbescherming}

Sinds 2017 is de Wet Inspectie Biociden BES van kracht (https://wetten.overheid.nl/jci1.3:c:BWBR0028563\&z=2012-07-28\&g=2012-07-28). Daarin staat dat de inspectie Volksgezondheid tot taak heeft toezicht te houden op de naleving van de wettelijke regelingen op het gebied van bestrijdingsmiddelen, gewasbeschermingsmiddelen, biociden en milieuaangelegenheden. De Rijksdienst Caribisch Nederland meldt op zijn website: 'Op dit moment is er nog geen op het gebruik op de BES-eilanden toegespitste formele toelatingsprocedure voor gewasbeschermingsmiddelen. Dit kan leiden tot een verhoogd risico op verkeerd gebruik. Ook is de kennis van risico's bij sommige gebruikers beperkt. Bovendien zijn de etikettering en de gebruiksaanwijzing soms in een onbekende taal geschreven. De Overheid geeft aan dat de lijst van vergunningsplichtige en verboden stoffen zal worden geactualiseerd. Zo is helder welke stoffen slechts met een vergunning mogen worden gebruikt en welke stoffen geheel verboden zijn.' (www.rijksdienstcn.com/landbouw-natuur-voedselkwaliteit/landbouw-tuinbouw-voedselkwaliteit).

\section{Aandacht voor een juist (volgens het etiket) gebruiken van toegelaten} gewasbeschermingsmiddelen is belangrijk. In kleine verpakkingen worden allerlei middelen verkocht voor huis- en tuingebruik. Voorlichting is noodzakelijk, daar men zich soms niet realiseert dat deze middelen gevaarlijk kunnen zijn. Tot voor kort kwamen goedkope gewasbeschermingsmiddelen uit Venezuela waaronder ook middelen die in Nederland al lang verboden voor gebruik in de landbouw zijn (J.J. van Almenkerk, pers. comm.).

\subsubsection{Dierenwelzijn en voedselveiligheid}

Dierenwelzijn en voedselveiligheid op Bonaire, Saba en Sint Eustatius is momenteel de verantwoordelijkheid van de lokale autoriteiten zelf. Daar Europese en Nederlandse regelgeving niet van toepassing is in Caribisch Nederland, behoudens uitzonderingen, geldt er geen wetgeving die volledig vergelijkbaar is met bijvoorbeeld de Wet dieren. Concreet betekent dit dat bijvoorbeeld het EU-verbod op het legbatterijsysteem niet geldt in Caribisch Nederland.

De bescherming van het dierenwelzijn is op de drie eilanden geborgd in artikel 477 van het Wetboek van strafrecht BES waarin dierenmishandeling en -verwaarlozing strafbaar gesteld is. In Artikel 18.2.4 van de Invoeringswet openbare lichamen Bonaire, Sint Eustatius en Saba staat dat bij of krachtens 
algemene maatregel van bestuur regels gesteld kunnen worden over het doden van dieren en de productie van vlees na het slachten van dieren. Bonaire en Sint Eustatius kennen eilandregelgeving waarin elementen zijn opgenomen die mede strekken tot bescherming van het dierenwelzijn (https://zoek.officielebekendmakingen.nl/kst-34550-IV-Q.html). Op Bonaire is onder andere het Besluit slacht- en vleeskeuring BES sinds 2010 van kracht (Besluit slacht- en vleeskeuring BES) en op Sint Eustatius Besluit slachten en verkopen van vee (Besluit slachten en verkopen van vee op Sint Eustatius).

Het Bestuurscollege Bonaire heeft een werkgroep dierenwelzijn opgericht die onder andere tot taak heeft een integraal plan te ontwikkelen: knelpunten in kaart brengen en voorstellen doen om de wetgeving dierenwelzijn te actualiseren (Bestuursprogramma bestuurscollege Bonaire 2019-2023). Deze studie heeft geen documentatie opgeleverd over hoe het op de andere eilanden gesteld is met dierenwelzijn of hoe het staat met de voedselveiligheid.

De Inspectie Gezondheidszorg en Jeugd is belast met het toezicht op de uitvoering van de gezondheids- en de veterinaire controles. Er wordt onderzocht of op het gebied van dierziektebestrijding en de toelating van diergeneesmiddelen verbeteringen mogelijk zijn (https://www.rijksdienstcn.com/landbouw-natuur-voedselkwaliteit/landbouw-tuinbouwvoedselkwaliteit).

\subsection{Veiligheid/diefstal 'buitengebied'}

Uit interviews, die in het kader van het opzetten van het plan van aanpak voor een geprofessionaliseerde geitenhouderij op Bonaire zijn gehouden, kwam naar voren dat de veiligheid met name ten aanzien van diefstal van bijvoorbeeld vee of machines en aanvallen op vee door loslopende honden, in het kunuku gebied verbeterd zou moeten worden voordat stakeholders willen investeren in de geitenhouderij (Bos \& Neijenhuis, 2018).

Veel bewoners wonen door de week in de bebouwde kom van bijvoorbeeld Kralendijk en zijn alleen in het weekend op de kunuku. Meer permanente bewoning van de kunuku's zou meer toezicht geven waardoor er minder gelegenheid is voor diefstal. Een verbetering van de nutsvoorzieningen buiten de bebouwde kom zou het gemakkelijker kunnen maken dat de Bonairianen overgaan tot meer permanente bewoning van het platteland, en zo de leefbaarheid van de kunuku's verbeteren. Een andere mogelijkheid is om de aanwezigheid van politie of andere opsporingsambtenaren op het platteland te verhogen en zo meer toezicht, controle en handhaving mogelijk te maken. Daarnaast is het geografisch clusteren van initiatieven ook een mogelijkheid waarbij de initiatiefnemers elkaar helpen met toezicht voor betere sociale controle.

Op Sint Eustatius en Saba lijkt de veiligheid op het platteland geen probleem.

Sowieso zullen initiatieven om te komen tot een verbeterde voedselproductie in het buitengebied in het algemeen gebaat zijn bij een structurele aanwezigheid van de initiatiefnemer/eigenaar of een beheerder/uitvoerder.

\subsection{Afzetmogelijkheden/belemmeringen in de keten}

De meeste lokaal geproduceerde verse landbouwproducten vinden goed aftrek onder de plaatselijke bevolking van de eilanden. Dit geldt voor kleinvee en ook voor basale plantaardige landbouwproducten. De winstgevendheid is echter beperkt omdat lokale producten veelal moeten concurreren met een overvloed aan goedkopere import. Versheid, bijvoorbeeld van groenten, biedt echter een concurrentievoordeel. De importproducten zijn vaak minder vers. Industrie om 
landbouwproducten te verwerken tot houdbare eindproducten is nog weinig ontwikkeld en biedt mogelijkheden voor ontwikkeling.

Afzetmogelijkheden naar toeristen op de eilanden zijn op dit moment nog beperkt. Toeristen nemen namelijk doorgaans heel weinig landbouwproducten af uit de lokale markt of supermarkt. Rauwe onverwerkte producten kunnen bijvoorbeeld door toeristen niet worden meegenomen. Toch kunnen lokale voedselproducten van wege genoemde versheid voor toeristen aantrekkelijker zijn dan geïmporteerde producten.

De afzet van reguliere versproducten naar toeristen vindt op dit moment grotendeels plaats via consumptie in gerechten in restaurants en hotels (Figuur 6). Daarnaast zouden bewerkte agrarische producten (bv. leerproducten, cactuswijn, lokale honing, jams, siroop, extracten, kruidentheeën) een breder verkoopkanaal naar toeristen kunnen krijgen, naast de huidige verkooppunten (souvenirshops). Voor sommige van dit soort producten (bv. souvenirs van de schelp van de kroonslak) kunnen exportbeperkingen gelden.

Op Bonaire worden lokale honing, jams en siroop verkocht. Er is een project geweest voor de verwerking van geitenleer. Dit project is afgerond. Momenteel wordt er op Bonaire geen geitenleer meer bewerkt. Ook hier is het een probleem dat men moet concurreren met goedkope import van geitenleren producten (J.J. van Almenkerk, pers. comm.). Er zijn inmiddels drie lokale producenten van rum. Ook wordt het lokale zout verkocht in verpakkingen speciaal voor toeristen (J.J. van Almenkerk, pers. comm.).

De exportmogelijkheden van voedsel zijn beperkt. De drie eilanden kunnen namelijk in productieprijs moeilijk concurreren met de grotere economieën, met name door gebrek aan mechanisatie en de beperkte schaal van productie. De export van basale voedselproducten (groenten, vlees, vis), zoals vroeger het geval was met exporten van agrarische producten naar Curaçao, biedt daarom op dit moment weinig kansen. Beperkende wetgeving (inzake fytosanitaire eisen elders, importheffingen), hoge eisen t.a.v. kwaliteit in de importerende landen en transportkosten vormen daarnaast belangrijke knelpunten en/of belemmeringen.

Exportmogelijkheden liggen er mogelijk wel op het gebied van de meer luxe verwerkte verzorgingsproducten (b.v. op basis van Aloë vera) of bovengenoemde voedingsproducten voor toeristen. De aanwezigheid van een verwerkende industrie om seizoensgebonden productie te verwerken tot houdbare en eindproducten met meerwaarde, zou de winstgevendheid van lokale landbouw aanzienlijk vergroten (M. Adriaens, pers. comm.).

Voor Saba biedt de op export naar Sint Maarten gerichte teelt van bloemen (Heliconia, Strelitzia), gember en kruiden theesoorten (bush tea) kansen voor de tuinbouwsector (DLG, 2012). Deze studie heeft geen documentatie opgeleverd over in hoeverre deze mogelijkheden voor export van genoemde meer luxe producten inmiddels gerealiseerd worden.

\subsection{Lokale cultuur}

De historische en culturele context is waarschijnlijk van belang om de verschillen tussen de eilanden te begrijpen en kan ook bijdragen aan begrip waarom bepaalde ontwikkelingen ter stimulering van lokale voedselproductie minder snel worden opgepakt dan de overheid graag zou willen. Zo heeft Saba nooit een plantagecultuur gekend, o.a. door de kolonisatie door kleine Engelse tuinders die meer gericht waren op kleinschalige thuisteelt, en is men gewend om voor eigen gebruik thuis gewassen te verbouwen. Bonaire heeft wel een belangrijke plantagecultuur gehad en kent ook thuisteelt. Bonaire is daarnaast meer internationaal georiënteerd door het toerisme en betere bereikbaarheid. Sint Eustatius heeft ook een plantagecultuur gekend en heeft een meer ontwikkelde Afro-Caribische cultuur. Echter, de nu voorliggende studie bood niet de ruimte om dieper in te gaan op hoe de lokale culturen op de eilanden de ontwikkelingskansen voor de landbouw beperken of juist zouden kunnen versterken. 


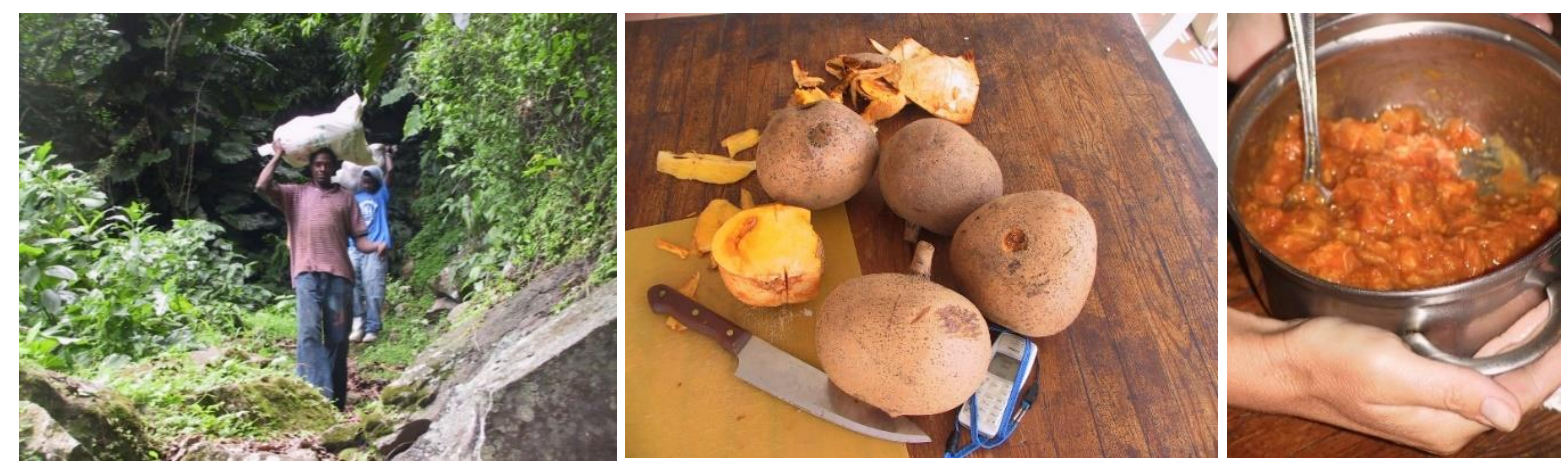

Figuur 6 De oogst van unieke bosbouwproducten voor levering aan lokale hotels op Saba: Mamey apple (Mammea americana), waarmee taarten en moes als ontbijtgerecht worden gemaakt. Van links naar rechts: de oogst uit het bos, de vruchten, en de moes. (Foto's: Dolfi Debrot). 


\section{Initiatieven om de voedselproductie te verhogen}

Dit hoofdstuk beschrijft enkele recente initiatieven ter verhoging van de lokale voedselproductie en bijbehorende kritische succesfactoren. Het projectteam richt zich op wat we hier vanuit de expertise ten aanzien van landbouw, tuinbouw en visserij kunnen leren. In deze studie kijken we niet naar de bestuurlijke context. De Algemene Rekenkamer is door het parlement gevraagd om onderzoek te doen naar de bijzondere uitkeringen die het kabinet verstrekt aan Bonaire, Sint Eustatius en Saba, waaronder die voor landbouwontwikkeling en natuur. De Algemene Rekenkamer zal in het onderzoek naar verwachting ook aandacht besteden aan de bestuurlijke en financiële verhoudingen tussen de rijksoverheid en de openbare lichamen op de drie eilanden.

Paragraaf 4.1 geeft een niet-uitputtend overzicht van initiatieven. Een aantal hiervan is ook reeds aan de orde gekomen bij de beschrijving van de huidige voedselproductie in Hoofdstuk 2. Vervolgens wordt ingezoomd op drie specifieke sectoren waar juist afgelopen jaren verschillende onderzoeken en initiatieven op gericht waren, namelijk oplossingen voor de geiten problematiek (4.2), innovatieve systemen voor groenteproductie (4.3) en stimulering van duurzame visserij (4.4).

In het algemeen kan gesteld worden: er zijn verschillende initiatieven ontplooid waarvan, zover we kunnen nagaan, meer gedetailleerde projectbeschrijving en verslaglegging in het openbare domein veelal ontbreken. Dit compliceert in dit onderzoek en daarbuiten, de duiding van de impact van deze initiatieven en wat we daaruit kunnen leren.

\subsection{Overzicht van initiatieven}

Om de afhankelijkheid van invoer van voedsel te verkleinen, zijn vanaf 2013 door de Nederlandse Overheid initiatieven genomen om de landbouwproductie op de eilanden te vergroten en is daar budget voor beschikbaar gesteld (via onder andere de "Regio Enveloppe"). Het ministerie van LNV onderzocht daartoe samen met de Openbare Lichamen en Nederlandse kennisinstituten naar mogelijkheden om een grotere en duurzame productie te realiseren (https://www.rijksdienstcn.com/landbouw-natuur-voedselkwaliteit/landbouw-tuinbouwvoedselkwaliteit). Hier volgt een beknopt overzicht.

Op Saba werd onder andere vanuit de Bijzondere Uitkering Natuur een project gestart om een oplossing te vinden voor de loslopende geiten die op de gemeenschappelijke gronden voor verlies aan biodiversiteit en erosieproblemen zorgen, en een project om de lokale voedselproductie te vergroten en te stimuleren. Op Sint Eustatius werd vanuit dit fonds ook een project gefinancierd om een oplossing te vinden voor loslopend vee dat op de gemeenschappelijke gronden voor verlies aan biodiversiteit en erosieproblemen zorgt. Over de bovenstaande projecten is weinig informatie te vinden. Aangezien in de Regio Enveloppe van 2018 ongeveer dezelfde speerpunten staan lijkt het erop dat de projecten nog niet (geheel) van de grond zijn gekomen. Ook wordt in de Regio Enveloppe een landbouwontwikkelingsproject op Saba genoemd waaronder de aankoop van landbouwgrond mogelijk wordt gemaakt (https://zoek.officielebekendmakingen.nl/kst-29697-54.html).

De basis voor de landbouwontwikkeling op Bonaire is de Beleidsvisie LVV 2014-2029. De Beleidsvisie LVV is in 2014 door het Bestuurscollege geaccordeerd. De vier speerpunten daarin zijn:

- Plattelandsontwikkeling

- Duurzame geitenhouderij

- LVV omvormen tot kenniscentrum en agro-bedrijvencentrum

- Duurzame visserij 
Op basis van de beleidsvisie zijn de volgende projecten reeds ontwikkeld:

- Plattelandsontwikkelingsprogramma POP Bonaire 2014-2019

- Plan van aanpak professionele geitenhouderij 2020-2028

- Reorganisatie en omvorming LVV vanaf 2020

POP Bonaire heeft volgens de geraadpleegde lokale experts (pagina 12) daarmee een basis gelegd voor:

1. Plattelandsontwikkeling

2. Het kenniscentrum landbouw

3. Toeristische ontwikkeling van het landelijk gebied

4. De ontwikkeling van marktgerichte tuinbouw

5. Professionalisering van de geitenhouderij

Gedetailleerde beschrijvingen van deze gelegde basis van elk van deze onderwerpen zijn (nog) niet voorhanden. Wel zijn er een aantal beknopte rapportages en zijn er handboeken gepubliceerd (zie hieronder).

Een project dat werd gestart voor Duurzame Landbouw en Plattelandsontwikkeling dat was voortgekomen uit het Plattelandsontwikkelingsplan (Openbaar Lichaam Bonaire \& het Ministerie van Economische Zaken, 2014), had onder andere als doel het achter hekken plaatsen van geiten en eigen centrale productie van voer voor de te houden geiten (Beleidsvisie landbouw, veeteelt en visserij Bonaire 2014-2029, 2014). Dit project wordt in het kader van de Regio Enveloppe (Kst 29697 nr. 54 d.d. 13 juli 2018) voortgezet om niet alleen de geitenproblematiek verder aan te pakken en centraal voer voor geiten te produceren met gezuiverd afvalwater, maar ook het slachthuis te verbeteren om zo de voedselveiligheid te vergroten (https://zoek.officielebekendmakingen.nl/kst-29697-54.html). Zie verder onder 4.2. In het kader van de ondersteuning van het ondernemerschap in het landelijk gebied heeft POP Bonaire op verzoek van de geitenhouders een aantal workshops georganiseerd over lamsvleesproductie en geitenmanagement.

Lokaal groente en fruit te verbouwen op de eilanden is zoals in eerdere hoofdstukken beschreven geen eenvoudige zaak. Een van de doelstellingen van het project Plattelandsontwikkelingsprogramma (POP Bonaire) is om een positieve bijdrage te leveren aan voedselproductie op het eiland, zowel voor eigen gebruik (bijvoorbeeld door introductie van kassen van 2 bij 3 meter voor eigen gebruik) als commerciële teelt voor restaurants en supermarkten. Hiervoor is educatiemateriaal ontwikkeld, vaak in drie talen (Nederlands, Papiamento en Engels) en een Facebook community opgericht (https://www.facebook.com/POPBonaire/). Resultaten zijn ook drie handboeken en video's over kleinschalige voedselproductie: Groente en fruit op Bonaire, basisboek (POP Bonaire \& Wayaká Advies, 2018); Handboek hydroponics on Bonaire, professionele teelt van sla (POP Bonaire, 2018); Handboek Professionele Groenteteelt Bonaire (Boers, 2016) en een video over professionele slateelt (https://www.youtube.com/watch?v=WIDn8XFrJD0\&feature=youtu.be).

De Dienst Landbouw, Visserij en Veeteelt van het Openbaar Lichaam Bonaire heeft in november 2020 12 kavels beschikbaar gesteld waarop telers groenten kunnen verbouwen. Volgens deze Dienst is daarmee de wens om de helft van de groenten en fruit op Bonaire lokaal te verbouwen, werkelijkheid aan het worden (Antilliaans Dagblad, 2020).

Door de Directie Samenleving en Zorg van het Openbaar Lichaam Bonaire zijn in 2017-2018 specifiek voor het onderwijs kassen geplaatst bij tien scholen en docenten aansluitend opgeleid (Bron: Ministerie van LNV, https://zoek.officielebekendmakingen.nl/kst-35000-IV-69.html). In dit kader zijn ook op Saba en Sint Eustatius bij scholen kassen geplaatst.

In 2019 is een MBO-1 Groen opleiding gestart met zes studenten. Deze opleiding is gericht op aanleg en onderhoud van tuinen. Het Basisboek Groenten en Fruit op Bonaire wordt behandeld in de opleiding. Aan het eind waren er drie geslaagden die nu ook een baan hebben. De andere drie studenten zijn door verschillende redenen vroegtijdig afgehaakt (J.J. van Almenkerk, pers. comm.). 
Door een tekort aan aanmeldingen (het betreft een beroepsbegeleidende leerweg) is deze opleiding in 2020 niet vervolgd (J.J. van Almenkerk, pers. comm.).

In juni 2020 is een rapport afgerond: Inventarisatie en behoefteanalyse groene sector Bonaire t.b.v. een op te zetten MBO-2 Groen (Aeres Hogeschool Wageningen en Wayaká Advies, 2020). Een

belangrijk advies is het aanbieden van een groene leerlijn vanaf de basisschool tot op het VMBO en MBO, zodat jongeren al vroeg met groene vakgebieden in aanraking komen (J.J. van Almenkerk, pers. comm.).

Vanuit de Regio Enveloppe werd op Saba een hydroponics farm gefinancierd (https://www.groentennieuws.nl/article/9051901/saba-gaat-hydroponic-teeltbedrijf-ontwikkelen/ ) en zijn vanuit een educatie/demonstratieplan kassen geplaatst bij twee scholen waarbij de docenten voor de daarbij horende kennisoverdracht werden geschoold (Anonymous, 2017b). Tevens zijn landbouwgronden op Saba in 2017 hersteld na orkaan Irma (https://www.rijksoverheid.nl/onderwerpen/regiodeals/documenten/kamerstukken/2019/09/20/kamerbrief-over-de-voortgang-uitvoering-regioenvelop-20182019).

Daarnaast is er een experimenteel onderzoekstraject van $€ 1000.000$ in 2017 gesubsidieerd door het Ministerie van Economische zaken, NWO en OCTA, waarin gezocht wordt naar alternatieve teeltmogelijkheden voor algen op Bonaire in het project Algae PARC (http://www.algaeparc.com/, https://www.dcbd.nl/sites/www.dcbd.nl/files/documents/BioNews27-AlgaePARC.pdf). Hierbij is onder andere Wageningen Universiteit \& Research betrokken met 2 PhDs. Het initiatief AlgaeParc Bonaire wil het niveau van voedselproductie en economische diversificatie op Bonaire verhogen door de duurzame productie van microalgen. Algen zijn rijk aan vetten en eiwitten waardoor het naast biobrandstof ook geschikt zou kunnen zijn als veevoer. Naast het maken van verschillende producten van microalgen, zal dit onderzoeksproject de basis kunnen leggen voor een nieuw energiepark. Dit energiepark zal Bonaire de energie geven die nodig is om hun doelstellingen op een duurzame manier te bereiken (http://www.algaeparc.com/projects/6/algaeparc-bonaire). Hoewel de R\&D perspectieven gunstig lijken zijn, is er nog geen concreet consortium voor daadwerkelijke exploitatie van de ontwikkelde methoden en technologie (I. Dominguez Teles, Wageningen University \& Research, pers. comm.).

Er zijn twee landbouwprojecten opgestart met de zouttolerante gewassen ijskruid en Aloë vera (https://zoek.officielebekendmakingen.nl/blg-822617). Deze projecten van zilte teelt van ijskruid en uitbreiding van Aloë vera zijn inmiddels afgelopen. In 2020 is aan 11 deelnemende telers een starterspakket uitgedeeld met daarin onder andere zaden van meerdere gewassen, zoutmeter en informatie (https://saltfarmfoundation.com/nl/bonaire/). Onderzoek bij de agrariërs is nog gaande. Ook is een project gefinancierd om onder andere het landbouwgebied Tras Montaña op Bonaire te revitaliseren https://www.eerstekamer.nl/overig/20171106/voortgangsrapportage_jaar_2016_van/document). Door landbouwmaatregelen (met name rasverbetering vee, importeren van geitenbokken, veevoerproductie op de kunuku) en het verbeteren van de toeristische voorzieningen in het gebied werd gepoogd het Tras Montaña gebied verder te ontwikkelen. Inmiddels is de toeristische infrastructuur in dit gebied verbeterd (https://www.explore-bonaire.com/.) Deze studie heeft geen informatie opgeleverd over resultaten van genoemde landbouwmaatregelen in Tras Montaña.

Rasverbetering en veevoerproductie vallen nu onder het Plan van aanpak op het LVV-terrein (zie 4.2).

Naast het gebruik van gezuiverd afvalwater voor de irrigatie van gewassen is er op Bonaire sinds juli 2018 een initiatief van de Coöperatie Agua Punta en SolteQ Energy om met een FreshWaterMill water voor landbouw te produceren. Dit gaat om een waterontziltingsinstallatie van $50 \mathrm{~m} 3 / \mathrm{dag}$ te starten op Bonaire (met een mogelijke volle capaciteit van $200 \mathrm{m3} / \mathrm{dag}$ ) in de omgeving Washikemba en Punta Blanku in het oosten van Bonaire (wateralliance.nl/freshwatermill-voor-landbouw-bonaire/). Hier wordt momenteel aan gewerkt (https://wateralliance.nl/solteq-energy-naar-bonaire-en-kaapverdie/).

Ook op Sint Eustatius wordt de beperkte beschikbaarheid van zoetwater voor irrigatie gezien als een van de grootste bottlenecks voor de landbouw en veeteelt. Daarom heeft LVV het initiatief genomen 
om een opvangbassin uit te graven dat met plastic wordt bekleed. Dit is bedoeld om het water van het zonnepanelenpark op te vangen en beschikbaar te stellen aan de tuinders (G. Lopes, pers. comm.). LVV gaat nóg een bassin maken voor opslag van regenwater wat een verdere expansie van landbouw op Sint Eustatius mogelijk zal maken (zie ook 3.1).

Bij het vergroten van de irrigatiecapaciteit door betere opvang van regenwater en het produceren van zoet water in ontziltingsinstallaties, zal ook aandacht gegeven moeten worden aan de governance en logistiek rond de verdeling van irrigatiewater, alsmede aan de beschikbaarheid en duurzame toepassing van meststoffen die voor een grotere productie noodzakelijk zijn.

\subsection{Geiten}

Van de problemen door vrij grazend vee zijn die van geiten het meest prominent. Geiten horen volgens (een deel van) de bevolking van Bonaire bij het platteland van Bonaire en zijn een belangrijk onderdeel van de cultuur (Openbaar Lichaam Bonaire \& het Ministerie van Economische Zaken, 2014). Loslopende geiten zijn (samen met de loslopende ezels) verantwoordelijk voor de hoge begrazingsdruk waardoor de hoeveelheid en diversiteit aan vegetatie afneemt, met erosie tot gevolg. De geiten lopen los in het kunukugebied en ook in het Washington Slagbaai National Park. Een telling door WUR eind 2014 gaf een schatting van 32.000 geiten op Bonaire waarbij de telling in het kunukugebied (plattelands- of landbouwgebied) erop wees dat $62 \%$ van de dieren in een omheinde kunuku stond, de rest liep buiten of kon door openstaande poorten en/of onvolledige omheining naar buiten lopen (Lagerveld et al., 2015). Loslopend vee veroorzaakt veel schade aan o.a. tuinen, aanplant en de natuur, en leidt tot erosie en stofoverlast. Zolang de geiten (en ezels) in de huidige aantallen los lopen is het telen van landbouwgewassen zonder de gronden volledig te omheinen, geen optie. Daartoe is dan ook actie wenselijk.

Mogelijke oplossingsrichtingen (scenario's) voor de loslopende geiten zijn in opdracht van Openbaar Lichaam Bonaire en ministerie van LNV door WUR onderzocht (Bos \& Neijenhuis (2018). De aanbevelingen zijn overgenomen in de Regio Enveloppe waar ook het verbeteren van het slachthuis om de voedselveiligheid te vergroten in is opgenomen (https://bonaire.nu/2019/09/20/regio-envelopfocust-voor-bonaire-op-vier-gebieden/, https://zoek.officielebekendmakingen.nl/kst-29697-54.html). Als alternatief voor de loslopende geiten wordt in dit plan op Bonaire ingezet op een meer professionele geitenhouderij waarbij veevoerproductie centraal op het eiland plaatsvindt voor de agrariërs die hun geiten achter de hekken op hun kunuku houden. Hiervoor is in samenwerking met Wageningen University \& Research ervaring opgedaan met veevoerproductie op basis van irrigatie met gezuiverd afvalwater op het LVV terrein (POP Bonaire, 2019).

Naast ruwvoerproductie, rasverbetering, identificatie en registratie van de geiten en betaalbaar hekwerk is in kader van een revitalisering van het kunukugebied ook veiligheid een punt van aandacht (diefstal en loslopende honden). In het plan van aanpak zijn verschillende fases gedefinieerd waardoor het ook beter mogelijk is om onderdelen die meer tijd vragen (zoals invoering en aanpassing van regelgeving) goed voor te bereiden, en verdere investeringen af te stemmen op de daadwerkelijke vraag en omvang van de veestapel.

- $\quad$ Fase I. Veevoerproductie op LVV-terrein met gezuiverd afvalwater, tegelijk plannen en opstarten water- en veevoerproductie op definitieve (grotere) locatie; systeem voor identificatie en registratie opzetten. (Jaar 1-2)

- Fase II. Praktijkdemonstratie met netwerk van circa 10 agrariërs en 1000 geiten; investeren in fokkerij gericht op verbetering vleesproductie en handhaving van het ingeschaard houden van de geiten. Monitoring en leren. (Jaar 2-4)

- $\quad$ Fase III. Wegvangen wilde (ongemerkte) geiten en ezels uit publieke ruimte. (Jaar 4-5)

- Fase IV. Opschaling veevoerproductie naar tweede (grotere) locatie op basis van ontzilt zeewater, indien haalbaar aangevuld met het plannen en opstarten water- en veevoerproductie op basis van oude de rioolwaterzuiveringsinstallatie op een derde locatie (Jaar 4-6)

- Fase V. Handhaving algeheel verbod op loslopende dieren. (Jaar 6-7) 
De plaatselijke agrarische coöperatie Kriabon heeft onder vijf voorwaarden ingestemd met het starten van het traject naar een geprofessionaliseerde geitenhouderij: 1. Betaalbaar veevoer, 2. Efficiënte waterdistributie, 3. Ondersteuning met afrastering, 4. Loslopende ezels aanpakken, en 5. Verbetering van de veiligheid van het kunukugebied, i.v.m. diefstal van vee en aanwezigheid van (verwilderde) honden.

De Raad voor de Rechtshandhaving (2019) maakt duidelijk dat om de problematiek rond loslopende geiten goed aan te pakken in elk geval ook het maken van regelgeving en het maken van afspraken met betrekking tot toezicht en handhaving belangrijk zijn.

De plannen voor de geitenproblematiek op Bonaire komen nu in uitvoering. Inmiddels is gestart met de bouw van het nieuwe slachthuis (4de kwartaal van 2020). Na renovatie is de beoogde slachtcapaciteit per dag: 150 schapen/geiten, 40 varkens, 5 runderen en 600 stuks pluimvee. In juni 2020 zijn voor het geitentraject zes vacatures voor projectleiders opengesteld (https://entrepreneurcaribbean.com/2020/06/10/projectleider-bij-de-overheid/). De projecten zijn inmiddels gestart (O. Creutzberg, Projectleider "professionalisering geitenhouderij en slachthuis" op Bonaire, pers. comm.).

Voor de productie van veevoer is ervaring opgedaan op het LVV terrein. Productie van de grascultivar Brachiaira Mulato II gaf goede opbrengsten (POP Bonaire, 2019; Köster, 2017). De beschikbaarheid van gezuiverd afvalwater (totaal ongeveer $400 \mathrm{~m}^{3}$ per dag) als irrigatiewater lijkt voldoende voor de productie van 10 hectare veevoer. Over de levering en de prijsstelling moeten nog wel afspraken worden gemaakt met het Bestuurscollege van Bonaire en het Water en Energiebedrijf Bonaire (WEB). Het WEB heeft ook afspraken gemaakt over het terug leveren van het gezuiverde afvalwater aan hotels. De totale productie lijkt voldoende om te leveren aan én de hotels én de veevoerproductie op het LVV terrein; de RWZI heeft een maximum-capaciteit van $1000 \mathrm{~m}^{3}$ per dag (Bos \& Neijenhuis, 2018; Wayaká Advies en BAAB BV., 2018). Volgens andere bronnen wordt het merendeel van het gezuiverde water (90\%) nu gebruikt door de hotels (M. Adriaens, pers. comm.).

De productie van geitenvlees als bedrijfseconomische activiteit zal naar verwachting alleen uitkunnen met subsidie op de kostprijs van het lokaal geproduceerde veevoer (Neijenhuis et al. 2016; Wayaká Advies en BAAB BV. 2018). Hiertegenover staan voordelen van dit productiesysteem, namelijk voor de geitenhouders, de telers zonder geiten, de bewoners van de steden en het gehele eiland zoals a) geen voedseltekort voor de geiten tijdens de droge tijd, b) betere waterinfrastructuur waarvan ook de tuinbouw profiteert, c) minder vraatschade in de landbouw en het publieke domein, en geen ernstige vraatschade in de natuur door geiten, d) een sterke toename in de soortenrijkdom in de natuur binnen enkele jaren als gevolg (Neijenhuis et al., 2016).

Naast de productie van gras als veevoer wordt nagegaan of het telen van onder andere de reeds aanwezige niet-inheemse eiwitrijke heester Moringa oleifera interessant kan zijn. Naast Moringa oleifera geeft de heer Adriaens (pers. comm.) aan dat ook de vlinderbloemigen Glircidia sepium en Leuceana leucocephala nader onderzocht zouden kunnen worden.

Bij de planvorming voor de ontwikkeling op Bonaire van geprofessionaliseerde geitenhouderij, zijn veel stakeholders bevraagd en betrokken bij de keuze van dit scenario. Er lijkt mede daardoor voldoende draagvlak voor de uitvoering. Omdat het totale plan ook de vitalisering van het kunukugebied beoogt (beschikbaarheid water, veiligheid), het financieel gesteund wordt vanuit de Regio Enveloppe en het lokaal aangestuurd gaat worden vanuit aangestelde projectleiders, heeft dit traject een reële kans van slagen.

Dankzij financiering vanuit zogeheten GroenFondsen (totaal €7.500.000) ging in 2014 het project "Goat eradication and control in Washington Slagbaai National Park" van start. Doel was om de loslopende geiten binnen het natuurreservaat Washington-Slagbaaipark uit te dunnen juist omdat er daar geen sprake was van de eigendomsvraag of weiderechten. Het project liep vanaf de aanvang enigszins moeizaam en resulteerde in onvoldoende effect. De verwijdering van geiten was minder dan de natuurlijke aanwas van geiten. Na het evaluatierapport voor het eerste jaar (Debrot, 2016) is het project derhalve stopgezet door het ministerie van LNV. Nieuwe pogingen van de Stichting Nationale 
Parken (Stinapa) Bonaire om zelfstandig het project aan te passen en door te zetten zijn door het ministerie niet gehonoreerd. Sindsdien heeft Stinapa zich vooral ingezet om wapenvergunningen rond te krijgen om daarmee de geiten af te schieten. Er is nu nog nauwelijks sprake van de ruiming van geiten in dit natuurreservaat.

Alhoewel een minder prominent probleem, zijn loslopende ezels kortstondig met meer succes aangepakt (Spoelstra, 2019). Tussen 2013 en 2016 werd in het kader van een overeenkomst tussen het Openbaar Lichaam Bonaire en de Donkey Sanctuary Bonaire (DSB) ezels gevangen en opgenomen. Dit om het aantal verkeersongelukken met ezels en overlast door ezels terug te dringen. Merries en veulens werden opgevangen in DSB, hengsten werden gecastreerd, gemerkt (met een oormerk en chip) en weer losgelaten (Spoelstra, 2019). Daardoor is in recente jaren het aantal loslopende ezels op het eiland merkbaar minder geworden. Door dit vang- en castreerprogramma is het aantal ezels in de DSB fors toegenomen tot ruim 700 dieren (Spoelstra, 2019). In het wild zijn er slechts ongeveer 100 merries die zich nog kunnen voortplanten. Daarnaast zijn er volgens Spoelstra (2019) maximaal 200 gecastreerde hengsten, 100 niet-gecastreerde hengsten en 100 veulens aanwezig.

Busby \& Rutland (2019) suggereren dat instandhouding van de Bonairiaanse ezel belangrijk is voor het geval dat het Afrikaanse ezelras waar deze ezels van afstammen, dreigt uit te sterven. Van de ezels op Bonaire zijn een beperkt aantal DNA-analyses beschikbaar, die inderdaad aan tonen dat de ezels afstammen van de wilde Nubische ezel (Spoelstra, 2019). Echter, hoe bijzonder de ezels zijn en in welke mate ze verwant zijn aan andere ezelpopulaties in het Caribisch gebied en met name de ezels op Aruba en Sint Eustatius is onbekend. Het is aan te bevelen om via DNA analyse variatie binnen de ezelpopulatie en verwantschap met andere populaties te laten onderzoeken (Spoelstra, 2019; E. Gus Cothran, Emeritus Professor Texas A\&M University, pers. comm.). Dit kan gedaan worden door het Centrum Genetische Bronnen Nederland, onderdeel van Wageningen University \& Research. Op basis van dergelijke analyses kan dan worden nagegaan of de ezels op Bonaire en bij voldoende verwantschap samen met ezels van Aruba en Sint Eustatius als een afzonderlijk ras kunnen worden beschouwd en als zodanig geregistreerd bij de FAO kunnen worden.

Ook op Sint Eustatius geeft geitenbegrazing een probleem (Debrot et al, 2015). Net als op Bonaire, werd een project gefinancierd (vanaf 2017) om de loslopende geiten aan te pakken (www.rijksdienstcn.com/landbouw-natuur-voedselkwaliteit/landbouw-tuinbouw-voedselkwaliteit) en moet het slachthuis worden gerenoveerd (https://zoek.officielebekendmakingen.nl/kst-34550-IVQ.html). Ondanks de goede intenties lijkt het aantal loslopende geiten sinds de eerdere telling weer te zijn toegenomen (Madden, 2020). Ook op Sint Eustatius is men nu bezig met ontwikkeling van nieuwe plannen om het loslopende geitenprobleem op te pakken (Anne de Boer, pers. comm.).

Tenslotte, ook op Saba is het oplossen van het probleem van loslopend vee (ook hier voornamelijk geiten) beschreven als een essentiële voorwaarde voor ontwikkeling van meer tuinbouw (DLG, 2012). Op Saba is daarom actief beleid gevoerd om het aantal loslopende geiten te verminderen. Dit programma staat bekend als de Goat Buy Back Project. In 2014-2016 zijn ruim 1400 geiten afgeschoten (Anonymous, 2017a). Omdat er geen geitentellingen zijn voor het eiland is echter onbekend of deze mate van afschot voldoende is om de geitenpopulatie te doen verminderen. Recent is er op het eiland weer aandacht voor het geiten probleem (M. van der Velde, pers. comm.). Door de Covid-19 beperkingen is er behoefte om meer groenten en kruiden in een eigen tuin te verbouwen om contacten te beperken. Loslopende geiten maken dit moeilijk of zelfs onmogelijk. Dit leidt recent tot nieuwe ruiming van loslopende geiten (https://www.saba-news.com/public-entity-saba-launches-itsgoat-control-project/).

\section{Samenvattend kan gesteld dat oplossingen voor de problemen door loslopende geiten vragen om (randvoorwaarden):}

- Een meerjarige aanpak als uitgangspunt, met goede kwantitatieve monitoring en rapportage, ook tussentijds.

- $\quad$ Een planvorming waarbij een brede betrokkenheid van de bevolking gewaarborgd is en waarbij ook rekening gehouden wordt met cultuuraspecten en andere factoren die maatschappelijke acceptatie bepalen. 
- $\quad$ Een systeemaanpak waarin de oplossing van het probleem van loslopende geiten direct gekoppeld is aan de ontwikkeling van een nieuwe en duurzame wijze van vleesproductie die goed past in de lokale context per eiland, met meekoppelkansen (win-win situaties) op gebied van bijvoorbeeld waterbeschikbaarheid, veiligheid, en verwerking en afzetmogelijkheden en waarbij de gerelateerde regelgeving gehandhaafd wordt.

Hoewel het nog te vroeg is voor een goed onderbouwde evaluatie van de brede aanpak van het geitenprobleem op Bonaire, is het met de huidige inzichten aannemelijk dat ook op Sint Eustatius en Saba een initiatief om het geitenprobleem op te lossen aan deze drie randvoorwaarden moet voldoen.

\subsection{Innovatieve systemen voor groenteproductie}

Er is een aantal initiatieven geweest, en die lopen deels nog, om groenteproductie te verbeteren. Deze initiatieven zijn vooral gericht op het stimuleren van het telen van eigen groente op "kunstgrond" (substraat) ter wille van een verbeterde kwaliteit, hygiëne en waterverbruik. Telen op een substraat of rechtstreeks in water kan voordelen hebben: a. beter/sneller groei door aangepaste wortelomgeving; b. kleiner kans op ziektes; c. verbeterde hygiëne; $d$. mogelijk waterbesparing door hergebruik van drainwater. De achterliggende verwachting is dat hiermee een constantere aanvoer van verse groenten te realiseren is met een efficiënter gebruik van water en nutriënten per kilogram groente. Met een extra investering om er een gesloten circulatiesysteem van te maken wordt het mogelijk om drainwater te hergebruiken. Hierdoor kun je op watergebruik sterk besparen en voorkom je dat nutriënten uitspoelen. Dit laatste heeft zowel een economisch als een milieutechnisch voordeel. Gezien de beperkte beschikbaarheid van water op de eilanden is een efficiënter gebruik van water zeer relevant. Ziektes en plagen vormen een groot probleem in de groenteteelt vooral wanneer in de volle grond geteeld wordt. In kassen zijn ziektes en plagen beter te beheersen.

Daarnaast is er veel synergie te behalen door het telen in kassen, omdat men dan ook enige controle heeft over de bovengrondse omgeving. Aangezien een foliekas heel gauw te warm wordt in dit deel van de wereld, is schaduwgaas genoeg om de planten te beschermen tegen zon en wind en om leguanen, hagedissen en vogels buiten te houden. Eigen voedselproductie op substraat in kleinschalige kassen (Figuur 7), is beschreven in het basisboek Plattelandsontwikkelingsprogramma POP Bonaire, Groente en fruit op Bonaire (POP Bonaire \& Wayaká Advies, 2018). Daarnaast zijn in 2017-2018 kassen geplaatst bij tien scholen en docenten aansluitend opgeleid (https://zoek.officielebekendmakingen.nl/kst-35000-IV-69.html); https://www.youtube.com/watch?v=C2LeNuqkTSA. Evaluatie van de impact van dit demonstratieproject is zover bekend nog niet gedaan/bekend.
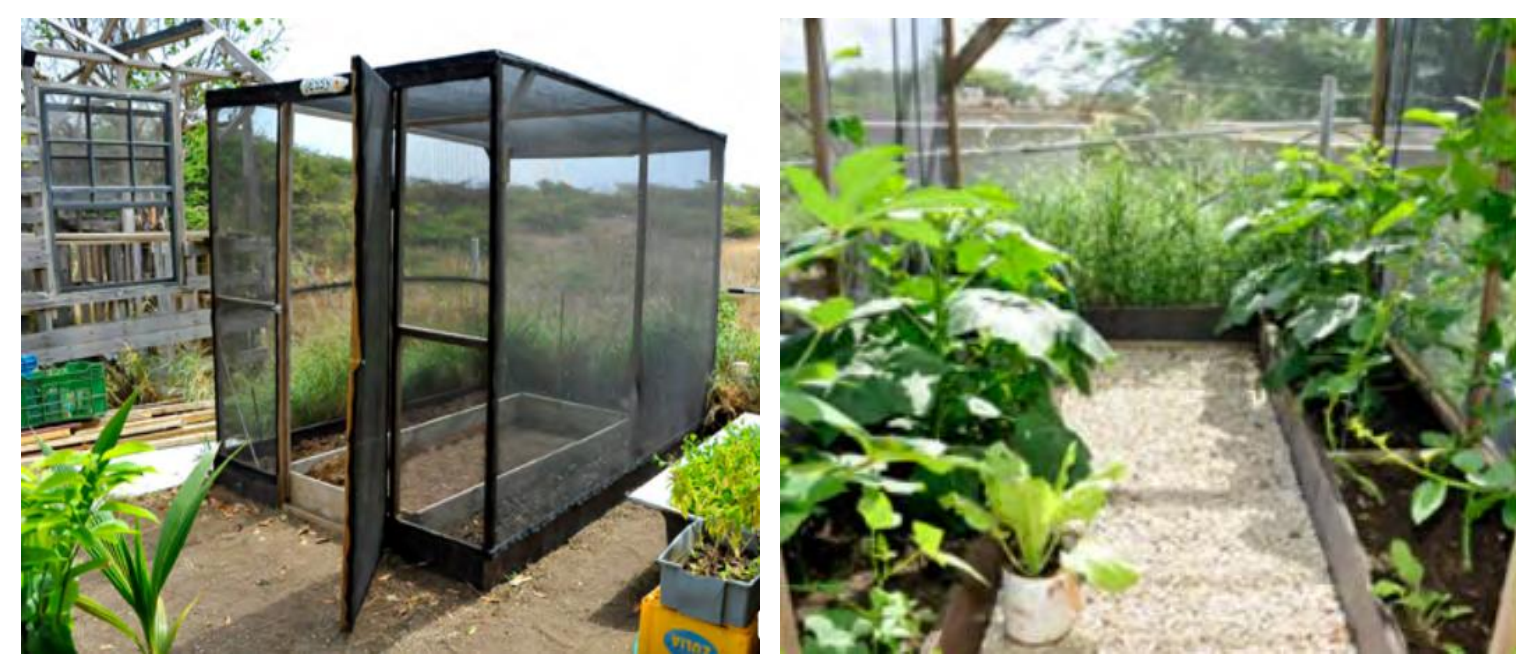
organisch/anorganisch materiaal (rechts). Bron: POP Bonaire \& Wayaká Advies, 2018. 
Closed loop hydroponics is in 2015 ingevoerd op een bedrijf op Bonaire voor de commerciële productie van sla op water (Figuur 8). De initiatiefnemers hiervan waren Jaap en Anneke van der Wel. Een tweetal informatieve filmpjes zijn gemaakt: https://www.youtube.com/watch?v=dzRggIuW8jE en https://www.youtube.com/watch?v=9gfgqLNarQY\&t=320s.

Vlak vóór hun terugkeer naar Nederland is een handboek vervaardigd in het kader van POP 2018: Handboek hydroponics op Bonaire, professionele teelt van sla (POP Bonaire, 2018), begeleid door een film: https://www.youtube.com/watch?v=WIDn8XFrJD0\&feature=youtu.be

Daarin wordt beschreven hoe met een bescheiden investering in materieel van US\$25.000 er met 26 uur werk per week 800 kroppen sla per week aan de supermarkten kunnen worden geleverd voor US\$ 800. De investering zou met 32 weken een relatief korte terugverdientijd hebben. De techniek werd in dit project ook geschikt bevonden voor de teelt van diverse andere bladgroentes zoals paksoi, basilicum en munt.

De haalbaarheid van hydroponics voor de lokale teelt van verse groenten is hiermee zo goed als aangetoond. Drie belangrijke suggesties van de initiatiefnemers (Jaap en Anneke van der Wel) waren: a) de noodzaak van regelmatige sterilisatie en schoonmaak met chloor om problemen met ziekten te voorkomen, b) de noodzaak voor dagelijkse toewijding en aandacht, en c) de lokale productie wordt beconcurreerd door import vanuit de VS. Om de lokale productie, en daarmee samenhangende lokale werkgelegenheid en zelfvoorziening stevig te verankeren is het wenselijk de lokale overheid samen met telers en andere betrokkenen een goed onderbouwde visie ontwikkelen over hoe de ervaringen in innovatieve groenteproductie benut kunnen worden om de winstgevendheid van de eigen voedselproductie te verhogen.

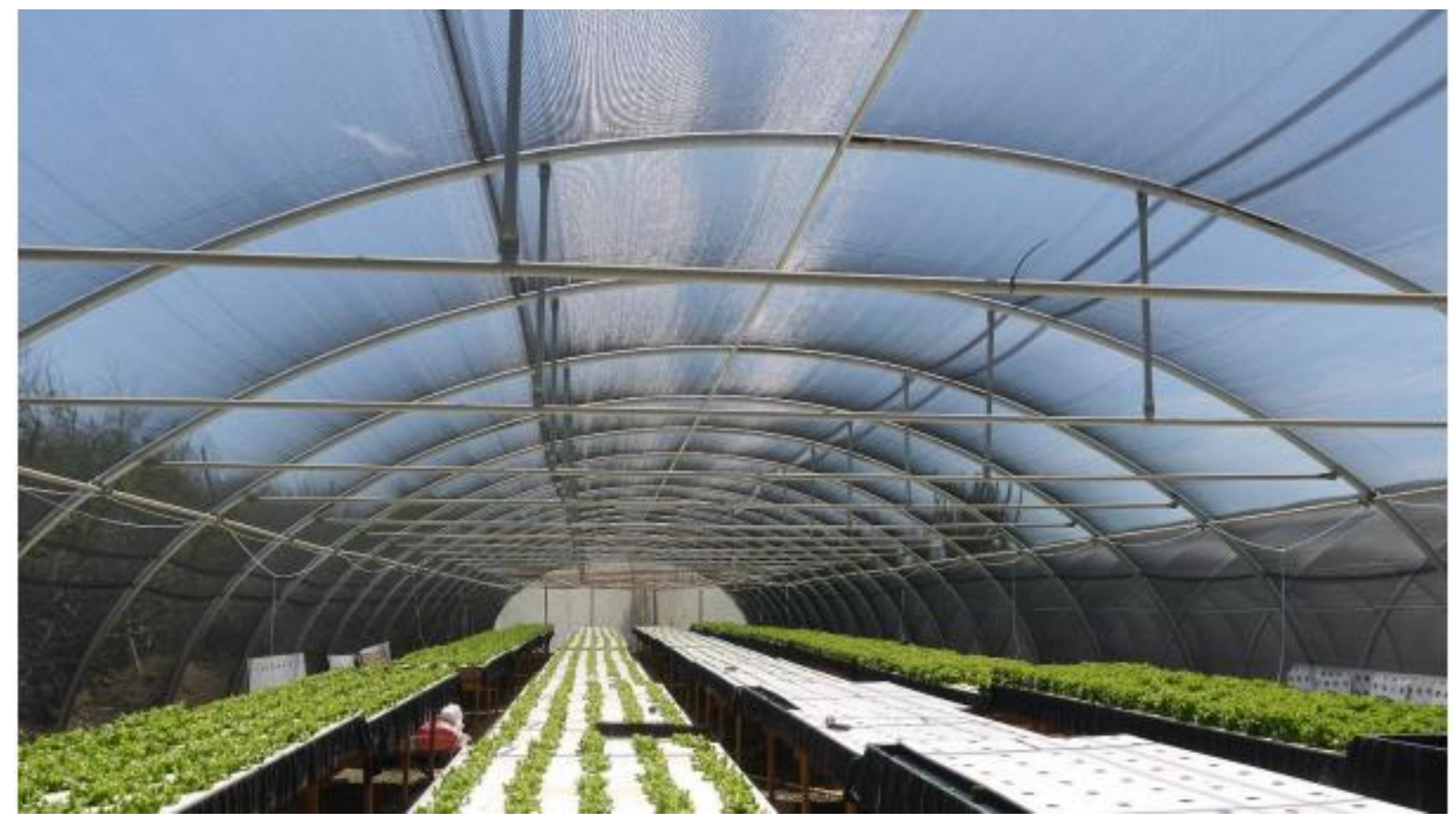

Figuur 8 Een kas $(50 \mathrm{~m} \times 10 \mathrm{~m})$ voor de commerciële productie van sla op water. Bron: Handbook Hydroponics op Bonaire (POP Bonaire, 2018).

Er bleek echter nog een belangrijk aandachtspunt. Het telen op water vereist een goede beheersing van de watertemperatuur. Op Bonaire is dit alleen mogelijk met koeling. Technische problemen hiermee hebben er voor gezorgd dat de productie op dit commerciële bedrijf in de volgende jaren tegen viel (J.J. van Almenkerk, pers. comm.).

Voor andere groenten en fruit met een langere teeltduur, is teelt op substraat echter geschikter dan op water. Ook op substraat is hergebruik van drainwater relatief 
gemakkelijk te implementeren. Het verzamelen en ontsmetten van drainwater vereist wel een extra investering.

Zulke investeringen zijn alleen rendabel in een beschermde omgeving van een [gaas]kas die groot genoeg is voor commerciële productie. Voor het beste resultaat zouden de eigenschappen van het gaas (vooral kleur en porositeit) afgestemd moeten zijn op het lokale klimaat (wind, minima en maxima temperatuur, zonnestraling) (Baeza et al., 2020). Gezien de klimaatverschillen tussen de eilanden en zelfs binnen een eiland zou hier in advisering met betrekking tot keuze van het gaas, rekening mee moeten worden gehouden (Hemming \& Baeza-Romer, 2019).

Teeltsystemen die gebaseerd zijn op relatief veel techniek, vereisen daarnaast ook technische affiniteit van de eigenaar, dan wel van het personeel. Daarom hoort bij een innovatieprogramma, gericht op het produceren van groenten met een hoge waterefficiëntie een gedegen opleidingsprogramma. Volgens de heer Adriaens (interim hoofd LVV) zijn praktische stages en opleiding op het bedrijf ook voldoende mits de deelnemers dan in Nederland naar eventueel noodzakelijke bijscholing kunnen. Een positief aspect is dat het hoog technisch gehalte van dit type landbouw juist aantrekkelijk kan zijn voor de jongere generaties.

Samenvattend, er is veel potentie voor een kwalitatief goede en waterefficiënte tuinbouw productie op hydroponics. Watercultuur is zeker geschikt voor bladgroente, maar vereist een relatief hoog niveau van techniek en deskundigheid. Gewassen met een langere teeltduur, zoals vruchtgroenten kunnen gemakkelijker geteeld woorden op substraat, wel met opslag en circulatie van drainwater. In alle gevallen dient de teelt te gebeuren in kassen aangepast aan de lokale omstandigheden. Om dit mogelijk te maken zijn echter projecten nodig gericht zowel op het optimaliseren van de teelt/kas naar de lokale markt en klimaat, als op het opleiden van capabele bedrijfsleiders en medewerkers. Daarnaast zullen er knelpunten blijken te zijn die nader onderzoek en ontwikkelen verlangen, zoals het probleem van de noodzakelijke koeling van het circulatiewater.

\subsection{Visserij - naar een meer gebalanceerd systeem}

Zoals in Hoofdstuk 2 beschreven, kan een deel van de visbestanden in de wateren van Caribisch Nederland beschouwd worden als overbevist (Graaf et al., 2015; Graaf et al., 2016; Debrot \& De Graaf 2018a, 2018b). Dit komt mede omdat de traditionele visserij zich vooral heeft gericht op toppredatoren (zoals de zeebaarzen) van het koraalrifecosysteem. Door de gangbare visserij te transformeren naar een visserij waar de focus lager in het voedselweb ligt en meer op het open water, is het mogelijk om tegelijk de netto vangst in kilogrammen te vergroten en het negatieve ecosysteemeffect te verminderen. Deze strategie heet in de wetenschappelijke literatuur "balanced fishing". Men gebruikt hiertoe vistechnieken die zich richten op de soorten die aan of nabij het wateroppervlak zwemmen (Couperus et al., 2014). Herstel van de riffen, hetzij door aanplant of de inzet van kunstriffen biedt mogelijk ook perspectieven voor herstel van de visstand (Hylkema et al., 2020; E. Boman, pers. comm.).

Het Natuur en Milieubeleidsplan 2020-2030 geeft aan dat verduurzaming van de visserij rond de drie eilanden belangrijk is. Genoemd worden onder andere dat nieuwe wettelijke kaders nodig zijn voor de visserij en de landbouw, dat er een visserijbeleidsplan in ontwikkeling is, de visserij zich meer moet gaan richten op "niet conventionele visbestanden", het belang van visserscoöperaties, en dat kustgebonden grote soorten zeebaarzen wettelijk beschermd moeten worden. In deze studie komen de genoemde componenten van dit plan aan de orde.

De visserij op Bonaire, Sint Eustatius en Saba is gebonden aan het ICCAT verdrag (International Commission for the Conservation of Atlantic Tuna). Dit verdrag reguleert vangsten van de grote meerbedreigde tonijnsoorten en tonijnachtigen. Nederland heeft zich via de EU gebonden aan dit verdrag. 
Voor alle drie eilanden geldt dat er goede kansen zijn om op duurzame wijze deze vangsten van soorten die aan of nabij het wateroppervlak zwemmen, te vergroten. Het gaat dan vooral om kleine schoolvormende roofvissoorten, zoals kleine tonijnen, makrelen en vliegende vissen. Verschillende van deze soorten verzamelen zich gemakkelijk rond zogeheten Fish Aggregating Devices (FADs). Dit zijn een soort boeien die verder uit de kust worden verankerd en daar vissen aantrekken. Interessante perspectieven voor de vergroting van de visvangst voor alle drie eilanden betreft het opzetten en beheren van een FAD-visserij die zich richt op genoemde schoolvormende vissoorten (Debrot \& Van der Burg 2019). Dat dit perspectieven biedt is al aangetoond op basis van de door de vissers zelf geplaatste FADs waarmee zij nu regelmatig grote vangsten realiseren (Zie Figuur 9). Op Bonaire is in 2019 ook begonnen met het plaatsen van FADs door de visserscoöperatie Piskabon.

Echter, een belangrijke voorwaarde voor de ontwikkeling van een duurzame visserij op alle drie eilanden is het monitoren van de vangsten om vroegtijdig ontwikkelingen (hetzij positief of negatief) te kunnen detecteren en dat naargelang van de uitkomsten van deze monitoring gehandeld wordt. Structurele vangstmonitoring vindt al een aantal jaren plaats op Saba en Sint Eustatius door zogeheten Data Management Offices (DMOs) gefinancierd door het ministerie van LNV. Op Saba is de DMO ondergebracht bij de Saba Bank Management Unit terwijl op Sint Eustatius de DMO eerst ressorteerde onder de Dienst LVV maar inmiddels is ondergebracht onder de CNSI (Caribbean Netherlands Science Institute). Dankzij dit monitoren zijn recent positieve ontwikkelingen in de redfish visstand en kreeftenstand van Saba waargenomen waardoor Wageningen Marine Research, onderdeel van Wageningen University \& Research, heeft geadviseerd dat een voorzichtige toename van de visserij wellicht mogelijk is (Graaf et al., 2017; Debrot \& De Graaf 2018a). Op basis hiervan zijn voor het jaar 2019 voor het eerst in lange tijd twee visvergunningen voor de Saba Bank gegund aan vissers van Sint Eustatius. In $\mathbf{2 0 2 0}$ is tevens besloten om een assistent voor de Saba DMO in dienst te nemen. Ook is besloten om voor het eerst een DMO functie voor Bonaire te creëren. Dit betekent dat spoedig ook structurele visvangst monitoring voor Bonaire mogelijk wordt.

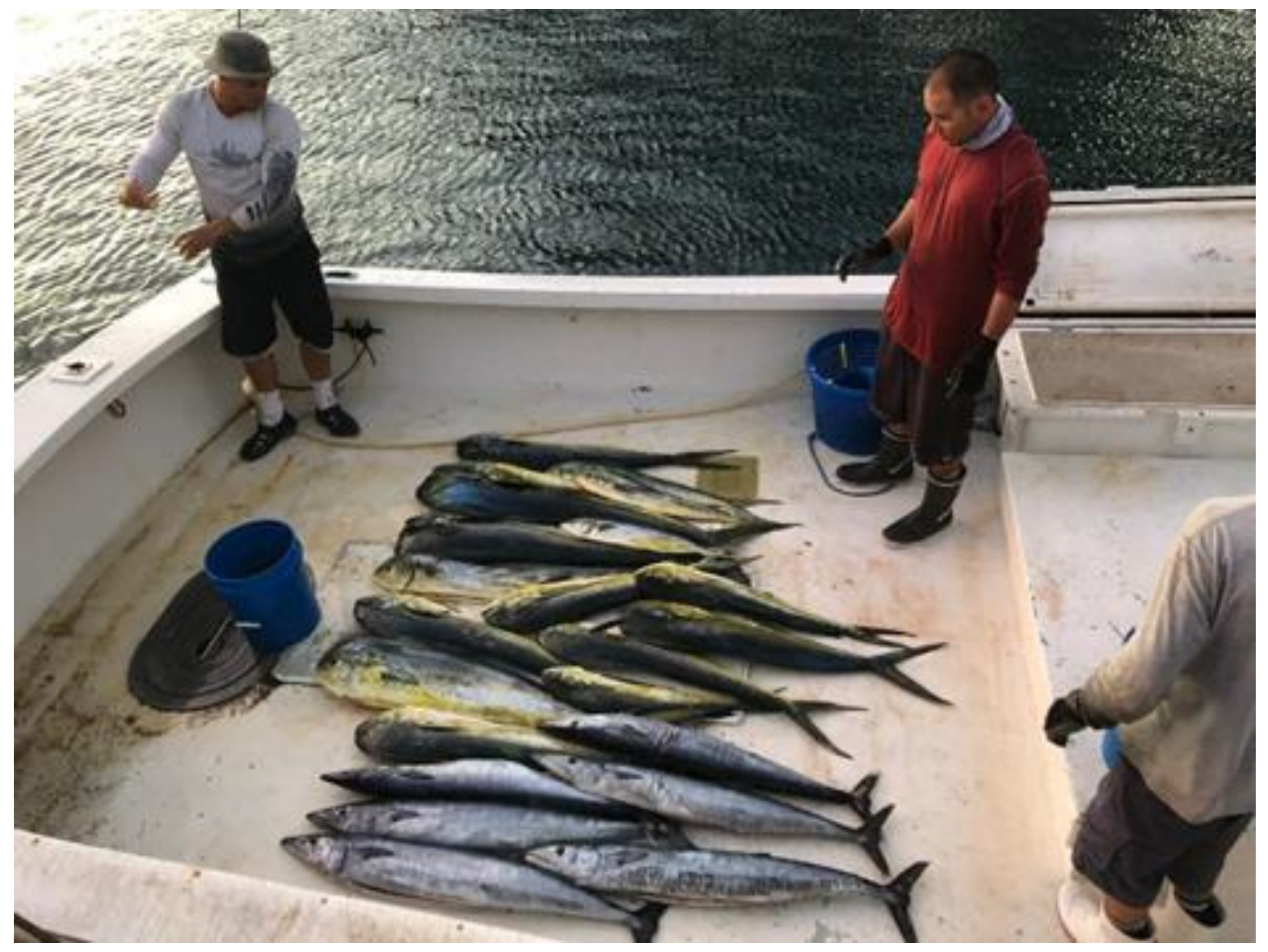

Figuur 9 De vangst van twee roofvissoorten (dorado en whaoo) dankzij de FAD-visserij. Uit monitoring blijkt dat beide soorten niet overbevist zijn in de regio (Foto: Ayumi Kuramae). 
Er bestaat een brede maatschappelijke wens om de visserij verder te verduurzamen. Naast de noodzaak voor het invoeren van beperkingen op de kustvisserij (koraalrifsysteem) is men ook in toenemende mate bewust van het belang van het zich richten op onderbenutte vissoorten doormiddel van een gereguleerde FAD visserij. Afgelopen jaren heeft vooral Bonaire belangrijke stappen met deze speciale vis aantrekkende boeien gemaakt. Niet alleen is door het ministerie en lokale partijen geïnvesteerd in de plaatsing van FADs rond Bonaire, maar is er tevens al een concept FAD beheerplan opgesteld door de visserscoöperatie Piskabon. Zover is men op Saba en Sint Eustatius nog niet. Er wordt wel gevist met FADs, maar dit vindt nog steeds plaats zonder wetenschappelijk onderbouwde richtlijnen of beperkingen.

Een belangrijke voorwaarde voor verduurzaming van de visserij is dat binnen de vissersgemeenschap eensgezindheid bestaat, de bereidheid tot samenwerking, en er concrete mogelijkheden zijn om te innoveren. Op dit vlak heeft vooral Saba grote stappen gemaakt. Er heerst al jaren goede samenwerking onder de vissers van het eiland. Zij zijn hierdoor instaat gebleken tot gezamenlijke besluitvorming om zich succesvol de nodige zelfregulatie op te leggen ter bescherming van de visstand. Voor de visstand van de Saba Bank bestaat er onder de vissers reeds gezamenlijk bewustzijn over de kwetsbaarheid van snappers en kreeften op overbevissing. Sinds 1 januari 2020 is ook de Saba Fishermen Association opgericht. Het Openbaar Lichaam Saba heeft dit proces gefaciliteerd en betaald. Rond de FADs is er wellicht nog geen sprake van overbevissing maar ook daar is het belangrijk goed te monitoren en op basis daarvan vangsten planmatig bij te sturen, voordat deze terugvallen of strenge beperkende maatregelen nodig worden. Op Bonaire is de visserscoöperatie Piskabon nieuw leven in geblazen en heeft deze voor de eigen organisatie ook een visbeheerplan opgesteld. Op Sint Eustatius is een visserscoöperatie momenteel in oprichting.

\section{Samenvattend:}

De ontwikkeling van visserij op meer open water en op soorten die aan of bij het wateroppervlak leven, biedt goede kansen tot duurzame uitbreiding van de visserijsector. Deze ontwikkeling dient gepaard te gaan met maatregelen om de algemene chronische overbevissing van de kustgebonden bodemvissen terug te dringen. Daarnaast is ook een structurele monitoring van de visbestanden essentieel. Hiermee kunnen ontwikkelingen in de visserij en visstanden vroegtijdig gesignaleerd worden en moet daar vervolgens adequaat naar gehandeld worden op basis van een vastgesteld beheerplan. Ook is het belangrijk dat er onder de vissers draagvlak bestaat voor duurzaam beheer. Om de hiervoor nodige bewustwording, eensgezindheid en samenwerking en innovatie te stimuleren en te onderhouden, biedt de oprichting en ondersteuning van vissers-coöperaties wellicht een uitkomst. De inzichten hier beschreven sluiten volledig aan op hetgeen voor de visserij is beschreven in het Natuur en Milieubeleidsplan 2020-2030. 


\section{Welke kansen geven de lessen uit het verleden in combinatie met nieuwe inzichten}

In Hoofdstuk 4 zijn recente initiatieven beschreven die ontplooid zijn om in Caribisch Nederland de landbouw en visserij verder te ontwikkelen en met name de lokale voedselproductie te stimuleren. Gedetailleerde projectbeschrijvingen van deze initiatieven en verslaglegging in het openbare domein zijn echter nauwelijks voorhanden. Dit compliceert de duiding van de resultaten en het afleiden van wat daaruit geleerd kan worden. Toch, met iets meer helicopterview, is wel degelijk te leren en zijn aanbevelingen te doen om de agrarische ontwikkelingsmogelijkheden in dit deel van Nederland te verbeteren.

Dit hoofdstuk beantwoordt de vraag welke lessen getrokken kunnen worden uit eerdere initiatieven in combinatie met nieuwe kennis en voortschrijdende inzichten, en welke nieuwe kansen dit oplevert voor de agrarische sector.

\subsection{Meer algemene lessen}

Op basis van de beschikbare literatuur en aanvullende expertkennis is een overzicht opgesteld van factoren die bepalend zijn voor de kansen van de landbouw (Hoofdstuk 3). Dit overzicht met zeven factoren is een bruikbare leidraad om te duiden op welke wijze de beschreven initiatieven bijdragen aan het verbeteren van de perspectieven van een hogere voedselproductie. Het gaat dan om:

- $\quad$ hoe water het meest efficiënt en duurzaam gewonnen, opgeslagen en ingezet kan worden voor voedselproductie,

- $\quad$ of er voldoende beschikbare kennis beschikbaar is waar op het eiland een geschikte agrarisch doel kan bereiken,

- hoe omgegaan kan worden met conflicterende belangen, bijvoorbeeld in grondgebruik, begrazingsmogelijkheden,

- hoe een effectieve regelgeving ontwikkeld en geëvalueerd kan worden die voldoende duurzaam geproduceerd voedsel faciliteert en zo nodig bijstuurt,

- hoe de algemene veiligheid in het buitengebied verbeterd kan worden,

- hoe toeleverende en afnemende sectoren optimaal kunnen functioneren, en

- hoe dit alles samenhangend past in een lokale eilandercultuur die verschilt per eiland.

Het zoeken naar mogelijkheden voor aansluiting bij recente nieuwe landelijke visies over gewenste ontwikkeling van een "natuurinclusieve" landbouw, die beter aansluit bij natuurlijke functies en natuurwaarden kan daarbij nuttig zijn (Verweij et al., 2020).

Ondanks het feit dat er door beperkte documentatie veelal geen goed onderbouwde evaluatie mogelijk is, voorzien de drie beschreven grotere initiatieven (geitenhouderij, innovatieve groenteproductie, gebalanceerde visserij) een aantal globale leerpunten en suggesties.

1. Meerjarige aanpak met kwantitatieve monitoring en doorlopende kennisontwikkeling. Of het nu voor vlees- of groenteproductie is of voor de visserij, in alle gevallen moet een meerjarige aanpak uitgangspunt zijn, met goede kwantitatieve monitoring en rapportage, ook tussentijds. Dat vraagt van beleid en alle andere betrokkenen, om langere tijd consistent naar een bepaald doel toe te werken, ook bij veranderende omstandigheden, bv door veranderende politieke constellatie, of gevallen dat sleutelpersonen de relatief kleine eilandgemeenschap verlaten, of zoals bij het hydroponics-project, er een technisch korte-termijn knelpunt blijkt te zijn. 
Kennisontwikkeling en -borging dienen mee te blijven lopen bij de ontwikkeling van deze initiatieven.

2. Systeemintegratie van te bereiken doelen, rekening houdend met cultuuraspecten. Een planvorming is nodig waarbij een brede betrokkenheid van de bevolking gewaarborgd is en waarbij ook rekening gehouden wordt met cultuuraspecten en andere factoren die maatschappelijke acceptatie bepalen. Dit zal waarschijnlijk het beste kunnen met een systeemaanpak waarin de oplossing van het probleem, bijvoorbeeld van de loslopende geiten, direct gekoppeld is aan de ontwikkeling van andere doelen, bijvoorbeeld veiligheid op het platteland of een verbeterde watervoorziening. Zulke duidelijke meekoppelkansen die goed passen in de lokale eilandcontext, zullen het noodzakelijke draagvlak van het initiatief kunnen vergroten.

3. Kennisimplementatie en innovatie met impact. Zoals op vele plekken in de wereld, hebben beroepscoöperaties op deze eilanden (zoals bijvoorbeeld van groentelers of vissers), een belangrijke rol in kennisimplementatie en innovatie. Op de eilanden met elk een eigen cultuur, zijn deze coöperaties mogelijk van extra belang voor een breed gedragen, consistente ontwikkeling naar een duurzamere productie van voldoende voedsel. De openbare lichamen en het Ministerie van LNV zouden kunnen nagaan hoe zij in de toekomst deze rol van coöperaties nog gerichter kunnen faciliteren.

\subsection{Zoetwater}

Beschikbaarheid van water van voldoende kwaliteit voor de teelt van gewassen en veeteelt is op alle drie de eilanden essentieel voor verdere ontwikkeling van een duurzame voedselproductie. Een geactualiseerd integraal zoetwaterplan met een actualisatie van informatie over de situatie van het grondwater, en waar circulaire en waterbesparende agrarische productiesystemen deel van uit maken, is daarom cruciaal. Dit plan dient in kaart te brengen hoeveel water per doel benodigd is, hoe dat zich in de nabije en verdere toekomst ontwikkelt. Het plan dient ook een kader te bieden voor mogelijk conflicterende belangen en hoe daar mee om te gaan, bijvoorbeeld van beschikbaarheid van het schaarse water voor voedselproductie en voor hotels. Planmatig grondwaterbeheer, gestoeld op een adequate regelgeving, dient onderdeel te zijn van dit integraal zoetwaterplan. Met dit planmatig grondwaterbeheer dient voorkomen te worden dat grondwater overmatig benut wordt en daarmee verder verzilt.

\subsection{Landbouw}

Gekoppeld aan een integraal zoetwaterplan is een geactualiseerd agrarisch ontwikkelingsplan van belang. In dit plan moeten naast concrete acties ook kennisleemtes benoemd worden voor nader onderzoek, onder andere naar mogelijkheden voor duurzame intensivering van teelten en veehouderij, circulaire en waterbesparende teeltsystemen, nieuwe gewassen (waaronder droogtetolerant en zoutminnend met lokaal toegevoegde waarde), en het houden van nieuwe veerassen.

Er zijn geen recente bodemkaarten beschikbaar voor de drie eilanden. Update van de bodemkaarten, gepubliceerd in 1955 en 1968 is gewenst.

De update van bodemkaarten is niet alleen belangrijk voor een duurzaam bodembeheer en het beter benutten van kansen voor agrarische productie, maar dient uiteraard ook een breder, planologisch belang en bij het milieubeleid. Een duurzaam bodembeheer is van groot belang, zeker ook in de tropen.

Het Ministerie van Binnenlandse Zaken en Koninkrijksrelaties is verantwoordelijk voor de basisregistratie ondergrond. Wettelijke basis hiervoor is de Wet Basisregistratie ondergrond (zie https://wetten.overheid.nl/BWBR0037095/2020-01-01).

De basisregistratie bestaat uit 26 registratieobjecten (www.basisregistratieondergrond.nl/inhoudbro/registratieobjecten/). Het Ministerie van Landbouw, Natuur en Voedselkwaliteit is zogenoemde 
bronhouder voor de Bodemkaart, de Geomorfologische Kaart en de Grondwaterspiegeldieptekaart en bijbehorende gegevens (o.a. booronderzoek). LNV verleent Wageningen Environmental Research (onderdeel van Wageningen University \& Research) in kader van WOT (wettelijke onderzoekstaken) opdracht tot actualisatie en beheer van genoemde 5 registratieobjecten. Dat betekent dat met deze WOT-opdracht aan alle uit de wet voortvloeiende verplichtingen wordt voldaan. Vanuit de Basisregistratie ondergrond voldoet Nederland ook aan zijn INSPIRE verplichtingen, met als doel het harmoniseren en openbaar maken ruimtelijke gegevens voor milieubeleid (https://www.sikb.nl/datastandaarden/wet-en-regelgeving/inspire). Bonaire, Sint Eustatius en Saba (evenmin als Aruba, Curaçao en Sint Maarten) maken geen deel uit van genoemde WOT-opdracht.

De huidige regelgeving die relevant is voor verdere ontwikkeling van voedselproductie op de eilanden, is ingekaderd binnen de Invoeringswet BES (www.rijksdienstcn.com/landbouw-natuurvoedselkwaliteit/landbouw-tuinbouw-voedselkwaliteit). In bijzonder gaat het dan om fytosanitaire zaken, gewasbescherming en dierenwelzijn en voedselveiligheid. Deze regelgeving wijkt deels af van die in Europees Nederland. Aanbeveling aan de overheid is om de regelgeving zoals beschreven in paragrafen 3.5.1-3 op nut en werkbaarheid te evalueren. In bijzonder dient de lijst van vergunningsplichtige en verboden actieve stoffen in gewasbeschermingsmiddelen te worden geactualiseerd. Zo is duidelijk welke stoffen slechts met een vergunning mogen worden gebruikt en onder welke voorschriften, en tevens welke stoffen geheel verboden zijn. Deze informatie moet in de lokale talen beschikbaar zijn (Nederlands, Engels en Papiamento).

Veiligheid in het buitengebied van Bonaire wordt door betrokkenen een belangrijke voorwaarde genoemd voor verdere uitbreiding van duurzame voedselproductie. Het niveau van veiligheid kan verbeterd worden door een meer structurele aanwezigheid van eigenaren of beheerders waardoor er meer toezicht is op gewassen, dieren en installaties waarin geïnvesteerd is. Verhoging van de leefbaarheid door verbetering van de nutsvoorzieningen kan leiden tot meer bewoning in het buitengebied, en daarmee tot meer toezicht. Daarnaast is het clusteren van initiatieven ook een mogelijkheid waarbij de initiatiefnemers elkaar helpen met toezicht voor betere sociale controle. Tenslotte zou overwogen kunnen worden de aanwezigheid van politie of andere opsporingsambtenaren op het platteland te verhogen en zo meer toezicht (en daaraan gekoppeld handhaving) mogelijk te maken op investeringen ten behoeve van agrarische productie.

De drie eilanden kunnen op dit moment qua productieprijs moeilijk concurreren met het buitenland, met name door de beperkte schaal van productie. De winstgevendheid van de teelt van gewassen en het houden van vee is daardoor beperkt. Er zijn ten minste drie opties om hier iets aan te doen.

1. Ondernemers kunnen de winstgevendheid verhogen door hun productie te intensiveren, in zoverre het past binnen een geactualiseerd agrarisch ontwikkelplan (zie boven). De initiatieven beschreven in 4.2. (geiten) en 4.3 (innovatieve systemen voor groenteproductie) hebben als doel mogelijkheden te creëren om duurzaam te intensiveren.

2. De huidige wijze waarop ondernemingen de lage winstgevendheid compenseren met neveninkomsten uit toerisme, biedt echter ook nog nieuwe ontwikkelmogelijkheden.

3. In bijzonder lijkt de teelt van "specialty" gewassen een groter potentieel te hebben dan op dit moment wordt gerealiseerd. De mogelijkheden voor expansie van de teelt van aloë en cactus voor productie van luxe producten dienen nader onderzocht te worden. Ook de markt van andere luxe verwerkte producten met hoge marktwaarde per kilo, zoals leer, gedroogde tomaten, komkommers op zuur, sappen, chutneys, geconserveerd (gezouten, gedroogd, gerookt etc.) vlees en vis, verdient nader onderzoek. Lokale industriële verwerkingsmogelijkheden zijn echter essentieel om deze "value-added" producten te realiseren. 


\subsection{Visserij}

De ontwikkeling van visserij op meer open water en op soorten die aan of bij het wateroppervlak leven, biedt goede kansen tot duurzame uitbreiding van de visserijsector. Deze ontwikkeling dient gepaard te gaan met maatregelen om de overbevissing van de kustgebonden bodemvissen terug te dringen. Hiertoe dient een breed gedragen visserijontwikkelplan te worden geschreven met wetenschappelijk onderbouwde richtlijnen en met monitoringsdata als basis, om aan te geven wat concreet te doen staat om overbevissing te voorkomen.

\subsection{Onderwijs}

Het imago van werk in de land- en tuinbouw lijkt op de drie eilanden de laatste tientallen jaren gedaald te zijn. Onderzoek naar de mogelijkheden om dit imago te verbeteren, vooral bij jongeren, is gewenst. In elk geval dient in dit onderzoek mee genomen te worden of productiesystemen die meer gebruik maken van innovatie en techniek (inclusief ICT), de jongeren meer aanspreken. Ook is het relevant te weten wat jongeren vinden van een meer geprofessionaliseerde voedselproductie die direct gekoppeld is aan nevenactiviteiten (bijvoorbeeld gericht op toerisme of zorg). Op basis van de resultaten van dit onderzoek kan dan voor elk van de eilanden een onderwijsplan gemaakt worden om jongeren in Caribisch Nederland meer te interesseren de lokale

voedselproductie. Met dit plan kan een curriculum ontwikkeld worden voor het lokale onderwijs vanaf de basisschool en met focus op het middelbaar beroepsonderwijs.

Parallel aan het onderhavige onderzoek is door Aeres Hogeschool Wageningen en Wayaká Advies in 2020) een inventarisatie en behoefteanalyse gedaan voor een op te zetten MBO-2 Groen opleiding voor de groene sector op Bonaire (J.J. van Almenkerk, pers. comm.). Een belangrijk advies van deze parallel-studie is het aanbieden van een groene leerlijn vanaf de basisschool tot op het VMBO en MBO, zodat jongeren al vroeg met groene vakgebieden in aanraking komen. Realisering van dit initiatief op Bonaire en uitbreiding daarvan naar de andere twee eilanden, zal belangrijk kunnen bijdragen aan verbetering van de kansen om duurzame landbouw in Caribisch Nederland verder te ontwikkelen en te verankeren. 


\section{Dankwoord}

De auteurs bedanken de heren Maurice Adriaens (Interim-hoofd, LVV Bonaire), Jan Jaap van Almenkerk (Wayaká Advies), Sherwin Pourier (Bonaire Agri \& Aqua Business bv) en Olaf Creutzberg (Projectleider professionalisering geitenhouderij en Renovatie Slachthuis Bonaire, gedetacheerd vanuit Ministerie van Landbouw, Natuur en Voedselkwaliteit) van Bonaire, Menno van der Velde (Saba Government) van Saba en Gershon Lopes (Hoofd LVV) en Erik Boman (directeur STENAPA) van Sint Eustatius, voor het verschaffen van informatie en hun commentaar op een conceptversie van dit verslag. Ook maakten de auteurs dankbaar gebruik van informatie en commentaar ingebracht door Yoeri de Vries (Rijksdienst voor Caribisch Nederland), Anne de Boer (RVO), en Egbert Jongsma en Emily Meringa (Algemene Rekenkamer). 


\section{Literatuur}

Anonymous, 2017a. Goat Buy Back Project. BioNews 9. P 6-7.

Anonymous, 2017b. Horticultural Project. BioNews 9. P 10.

Antilliaans Dagblad, 2020. https://antilliaansdagblad.com/bonaire/22651-groente-en-fruit-van-eigen-eiland.

Baeza, E. J., van Breugel, A. J. B., Hemming, S. \& C. Stanghellini, 2020, Smart greenhouse covers: A look into the future. Acta Horticulturae. 1268, p. 213-224.

Beleidsvisie landbouw, veeteelt en visserij Bonaire 2014-2029, 2014. https://www.dcbd.nl/document/beleidsvisie-landbouw-veeteelten-visserij-bonaire-2014-2029

Boers, A., 2016. Handboek Professionele Groenteteelt Bonaire, 'Een praktisch handboek bedekte groenteteelt op Bonaire bedoeld voor (toekomstige) professionele telers'. Plattelandsontwikkelingsprogramma (POP) Bonaire. 64 pp. https://www.dcbd.nl/sites/www.dcbd.nl/files/documents/Handboek\%20Professionele\%20Groenteteelt\%20Bonaire_0.pdf

Bogaardt, M., R. de Jong, M. van der Heide, 2015. Voedselzekerheid op Bonaire, St. Eustatius en Saba. Aangrijpingspunten voor de beleidsinzet van het ministerie van Economische zaken. Nota LEI 2015-132, LEI Wageningen UR, Wageningen.

Borst, L. \& S.A.D. De Haas, 2005. Hydrological research Bonaire; a hydrogeological investigation of Bonaire's water system. Amsterdam: Acacia institute.

Bos, B. \& F. Neijenhuis, 2018. Plan van aanpak professionele geitenhouderij op Bonaire. Concept-rapport december 2018. Wageningen Livestock Research: Wageningen.

Briene, M., M. Bongenaar \& D. Bos, 2019. Duurzame ontwikkeling Bonaire, Sint Eustatius en Saba: Eindrapport. ECORYS. Rotterdam. 70 pp.

Burg, W.J. van der, J. de Freitas, A.O. Debrot \& L.A.P. Lotz, 2012. Naturalised and invasive alien plant species in the Caribbean Netherlands: status, distribution, threats, priorities and recommendations : report of a joint Imares/Carmabi/PRI project financed by the Dutch Ministry of Economic Affairs, Agriculture \& Innovation. PRI report 437, Imares report C185/11, Plant Research International, Wageningen UR, Wageningen

Busby, D. \& C. Rutland, 2019. The Horse; a natural history. Ivy Press, London. ISBN: 978-1-78240-565-8

Couperus, A.S., I.J.M. van Beek, A.O. Debrot, S.M.M. Fassler, S. Gastauer, 2014. A review of the small pelagics fishery resources of the Dutch Caribbean and adjacent areas. IMARES Report C142/14, 67 pp.

Debrot, A.O. ,2004a. Natuurlijke bronnen en putten. Amigoe, Ñapa, 4 September 2004, p5.

Debrot, A.O., 2004b. Natuurlijke bronnen en putten: Cultuurhistorisch erfgoed 2. Amigoe, Ñapa, 12 June 2004 , p5.

Debrot, A.O., 2004c. Natuurlijke bronnen en putten: Cultuurhistorisch erfgoed 3. Amigoe, Ñapa, 4 September 2004 , p5.

Debrot, A.O., 2016. Goat culling project Slagbaai, Bonaire: 1st Year Progress Report, Field Assessment and Key Recommendations. Unpublished IMARES-report C052/16, Wageningen University, Wageningen, The Netherlands. 46 pp

Debrot, A.O. \& M. de Graaf, 2018a. Saba bank fisheries: reasons for cautious optimism. Wageningen marine research Policy Brief, 26 February, 2018. 5 pp.

Debrot, A.O. \& M. de Graaf, 2018b. Chapter 3.10. Visstand. Pp. 156-173. In: A.O. Debrot, R.J.G.H. Henkens, P.J.F.M. Verweij: Staat van de natuur van Caribisch Nederland 2017. Wageningen Marine Research (University \& Research Centre) Report C086/17: 214 pp.

Debrot, A.O., J.C.J. Hazenbosch, S. Piontek, C. Kraft, J. van Belle \& A. Strijkstra, 2015. Roaming livestock distribution, densities and population estimates for St. Eustatius, 2013. Unpublished IMARES-report C088/15, Wageningen University, Wageningen, The Netherlands.

Debrot, D. (A.O.), \& S. van der Burg, 2019. Food from the Oceans. Factsheet 3. Nexus interventions for small tropical islands: case study Bonaire. 9 pp. In: Slijkerman, D. and M. van der Geest. 2019. (eds.). Nexus interventions for small tropical islands: case study Bonaire. WUR letter report 1900369.JA-ih. Wageningen, The Netherlands. 85 pp.

Debrot, A.O., A. Reid, T. Leslie, H. Madden, J. Stapel, F. Dalm, L. Uphoff \& L. van der Zwet, 2016. Encouraging results for controlling an agricultural pest on St. Eustatius. BioNews (DCNA Newsletter) 26:8

Debrot, A.O., M. Ruijter, W. Endarwin, P. van Hooft \& K. Wulf, 2014. Predation threats to the Red-billed Tropicbird breeding colony of Saba: focus on cats. IMARES Report C011/14, $53 \mathrm{pp}$.

DLG, 2011. Assessment of opportunities for sustainable agriculture and fisheries on St. Eustatius. Report of mission $13-21$ March 2011. DEZ, 39 pp.

DLG, 2012. Assessment of Opportunities for Sustainable land use on Saba. Final report. Utrecht.

Freitas, J.A. de, B.S.J. Nijhof, A.C. Rojer \& A.O. Debrot, 2005. Landscape ecological vegetation map of the island of Bonaire (Southern Caribbean). Royal Netherlands Academy of Arts and Sciences, Amsterdam. 64 pp. (+ maps) 
Freitas, J.A., de, A.C. Rojer, B.S.J. Nijhof \& A.O. Debrot, 2014. A landscape ecological vegetation map of Sint Eustatius (Lesser Antilles). Amsterdam: Amsterdam University Press. 67 pp.

Freitas, J.A., de, A.C. Rojer, B.S.J. Nijhof \& A.O. Debrot, 2016. A landscape ecological vegetation map of Saba (Lesser Antilles). Amsterdam: Amsterdam University Press.

Graaf, M. de, Brunel, T. Nagelkerke, L. \& A.O. Debrot, 2017. Status and trends Saba Bank fisheries: 2015. Unpublished WMR-rapport C077/17. $127 \mathrm{pp}$.

Graaf, M. de, E. Houtepen, E. Tichelaar, D.C.M. Miller, T. Brunel \& L.A.J. Nagelkerke, 2016. Status and trends reef fish and coastal fisheries Bonaire (Caribbean Netherlands): report card 2014-2015. Wageningen University \& Research rapport C087/16. 70 pp.

Graaf, M. de, S. Piontek, C.M. Miller, T. Brunel \& L.A.J. Nagelkerke, 2015. Status and trends of St. Eustatius coral reef ecosystem and fisheries: 2015 report card. IMARES report C167/15. $41 \mathrm{pp}$.

Grontmij \& Sogreah, 1968. Water and land resources development plan for the islands of Aruba, Bonaire and Curaçao. Report Grontmij (De Bilt): 133 pp.

Hardin, G., 1968. The Tragedy of the Commons. Science, 162: 1243-1248. DOI: 10.1126/science.162.3859.1243.

Hartog, J. , 1957. Bonaire, van indianen tot toeristen. Edited by De Wit. Aruba.

Hemming, S. \& A.J. Baeza-Romer, 2019, Effect of greenhouse films on climate, energy, light distribution and crop performance measuring film properties and modelling results. Acta Horticulturae. 1252, p. 173-181.

Hylkema, A., A.O. Debrot, R. Osinga, P.S. Bron, D.B. Heesink, A.K. Izioka., ... \& A.J. Murk, 2020. Fish assemblages of three common artificial reef designs during early colonization. Ecological Engineering 157, 105994.

KNMI, 2017. Klimaatverandering op de Caribische eilanden. https://www.knmi.nl/over-het-knmi/nieuws/klimaatverandering-op-decaribische-eilanden

Koninkrijk.nu, 2020. https://koninkrijk.nu/2020/04/24/st-eustatius-wil-drie-maal-meer-vlees-produceren.

Köster, H. W., 2015. Introductie en teelt op Bonaire van doornloze cactus voor geiten. POP Bonaire. 10 pp.

Köster, H.W. , 2017. Versterken van de ruwvoerproductie voor vlees-geiten op Bonaire. POP Bonaire. 86 pp.

Lagerveld, S., A.O. Debrot, P. Bertuol, N. Davaasuren \& F. Neijenhuis, 2015. Populatieschatting geiten op Bonaire. IMARES-report C115/15, Wageningen University, Wageningen, The Netherlands. 48 pp.

Madden, H., 2020. Survey of free roaming livestock of St. Eustatius. BioNews 33. 2 pp.

Ministeries van LNV, IW \& BZK, 2020. Plan voor land en water:: Beleidsplan Natuur en Milieu Caribisch Nederland 2020-2030. Kamerstuk 33 576, nr. 190. Ministeries van Landbouw, Natuur en Voedselkwaliteit, Infrastructuur en Waterstaat en Binnenlandse zaken en Koninkrijksrelaties. $52 \mathrm{pp}$.

Meindert, L.,M. Briene, E. Merkus \& R. van den Bergh, 2017. Onderzoek naar prijzen in Caribisch Nederland, Deel I: Eindrapport. Opdrachtgever Ministerie van Economische Zaken.

Neijenhuis, F. B. Bos \& A.O. Debrot, 2015. Beleidsadvies geitenhouderij op Bonaire. Wageningen UR Livestock International/IMARES. Wageningen University, Wageningen, The Netherlands. $44 \mathrm{pp}$.

Neijenhuis, F., I. Vermeij, B. Bos, 2016. Professionele ruwvoerproductie en geitenhouderij op Bonaire. Ongepubliceerd rapport. Wageningen Livestock Research: Wageningen. 42 pp.

Openbaar Lichaam Bonaire, 2014. Beleidsvisie 2014-2029. Landbouw, Veeteelt en Visserij, Bonaire. 46 pp.

Openbaar Lichaam Bonaire, 2018 . Beheerplan wegen Bonaire 2017-2026

Openbaar Lichaam Bonaire \& het Ministerie van Economische Zaken, 2014, Plattelandsontwikkelingsplan Bonaire. En nu aan de slag! 36 pp.

POP Bonaire, 2018. Handboek hydroponics op Bonaire: professionele teelt van sla. 16 pp. https://www.dcbd.nl/sites/www.dcbd.nl/files/documents/Handbook\%20Hydroponics\%20on\%20Bonaire.pdf

POP Bonaire \& Wayaká Advies, 2018. Groente en fruit op Bonaire, basisboek, 60 pp. https://www.dcbd.nl/sites/www.dcbd.nl/files/documents/Basisboek_Groente_en_fruit_op_Bonaire.pdf

POP Bonaire, 2019, Veevoerproductie op Bonaire 2015-2018, 5 pp.

Rijksbegroting, 2020. www.rijksbegroting.nl/2018/kamerstukken,2017/10/2/kst237563.html).

Roberts, M, N. Hanley, S. Williams, W. Cresswell, 2017. Terrestrial degradation impacts on coral reef health: Evidence from the Caribbean. Ocean \& Coastal Management 149: 52-68.

Rowbottom, R.J. \& C.W. Winkel, 1979. Well survey Bonaire. Department of Agriculture Curaçao: 42 pp.

De Raad voor de Rechtshandhaving, 2019. Handhaving natuur- en milieuwetgeving in Caribisch Nederland. Over loslopend vee, zwervend vuil en andere problemen voor de natuur op Bonaire, Sint Eustatius en Saba. Raad voor de Rechtshandhaving, Bonaire. $61 \mathrm{pp}$.

Rijksoverheid, 2018. Ruimtelijke Ontwikkelingsplan Bonaire (d.d. 31 juli 2018). Rho Adviseurs voor Leefruimte, Rapport: L.IMRO.0000.20170681-GC01, projectnummer: 20170681. 406 pp.

Sambeek, M. H. G., van, H.G.M. Eggenkamp \& M.J.M. Vissers. 2000. The groundwater quality of Aruba, Bonaire and Curaçao: a hydrogeochemical study. Geologie en Mijnbouw / Netherlands Journal of Geosciences 79 (4): 459-466. 
Slijkerman, D., M. van der Geest \& A.O. (D.) Debrot, 2019. Water. Factsheet 4. Nexus interventions for small tropical islands: case study Bonaire. 9 pp. In: Slijkerman, D. and M. van der Geest. 2019. (eds.). Nexus interventions for small tropical islands: case study Bonaire. WUR letter report 1900369.JA-ih. Wageningen, The Netherlands. 85 pp.

Smith, S.R., W.J. van der Burg, A.O. Debrot, G. van Buurt \& J.A. de Freitas, 2014. Key Elements Towards a Joint Invasive Alien Species Strategy for the Dutch Caribbean. IMARES Report C020/14, 104 pp.

Sociaal Cultureel Planbureau, 2015. Vijf jaar Caribisch Nederland. 343 pp.

Spoelstra, S.F., 2019. Ezels op Bonaire: Achtergrondrapport voor beleidsadvies over de toekomstige positie van ezels op Bonaire aan Openbaar Lichaam Bonaire en het Ministerie van Landbouw van Bonaire. Stichting KibraHacha, Bonaire. 52 pp.

UNICEF NL, 2019. Situatieanalyse kinderen en jongeren in Caribisch Nederland. 126 pp.

Veenenbos, J.S., 1955. A soil and land capability survey of St. Maarten, St. Eustatius, and Saba. Publ. Found. Sci. Res. Sur. Neth. Ant., Utrecht, The Netherlands. 11, 94 pp., ill., map.

Verweij, P., A. Cormont, J. Nel, B. de Rooij, L. Jones-Walters, D. Slijkerman, K. Soma \& M. van Eupen, 2020. A nature inclusive vision for Bonaire in 2050. Wageningen Earth Observation and Environmental Informatics Report 3023, ISSN 1566-7197, 40 pp.

Wagenaar-Hummelinck, P., 1979. Caves of the Netherlands Antilles. Fnd. Sci. Res. Surinam \& Neth. Antilles, Utrecht, The Netherlands. $176 \mathrm{pp}$.

Wayaká Advies \& BAAB BV, 2018. Business Case Veevoerproductie Bonaire. In opdracht van Wageningen Livestock Research. 28 pp. 
Correspondentie adres voor dit rapport:

\section{Postbus 16}

6700 AA Wageningen

T 0317480700

www.wur.nl/plant-research

Rapport WPR-1026
De missie van Wageningen University \& Research is 'To explore the potential of nature to improve the quality of life'. Binnen Wageningen University \& Research bundelen Wageningen University en gespecialiseerde onderzoeksinstituten van Stichting Wageningen Research hun krachten om bij te dragen aan de oplossing van belangrijke vragen in het domein van gezonde voeding en leefomgeving. Met ongeveer 30 vestigingen, 5.000 medewerkers en 10.000 studenten behoort Wageningen University \& Research wereldwijd tot de aansprekende kennisinstellingen binnen haar domein. De integrale benadering van de vraagstukken en de samenwerking tussen verschillende disciplines vormen het hart van de unieke Wageningen aanpak. 